\title{
Interactive effects of acidification, hypoxia, and thermal stress on growth, respiration, and survival of four North Atlantic bivalves
}

\author{
Alexandra M. Stevens, Christopher J. Gobler* \\ Stony Brook University, School of Marine and Atmospheric Sciences, 239 Montauk Hwy, Southampton, NY 11968, USA
}

\begin{abstract}
We investigated the individual and interactive effects of coastal and climate change stressors (elevated temperatures, acidification, and hypoxia) on the growth, survival, and respiration rates of 4 commercially and ecologically important North Atlantic bivalves: bay scallops Argopecten irradians, Eastern oysters Crassostrea virginica, blue mussels Mytilus edulis, and hard clams Mercenaria mercenaria. Month-long experiments were performed on multiple cohorts of post-set juveniles using conditions commonly found during summer months within eutrophied, shallow, temperate, coastal environments $\left(24-31^{\circ} \mathrm{C}_{i} 2-7 \mathrm{mg} \mathrm{O}_{2} \mathrm{l}^{-1} ; \mathrm{pH}_{\mathrm{T}}\right.$, total scale, 7.2-8.0). Elevated temperatures most consistently altered the performance of the bivalves, with both positive and negative physiological consequences. Low levels of dissolved oxygen (DO) and $\mathrm{pH}$ individually reduced the survival, shell growth, and/or tissue weight of each bivalve, with $A$. irradians being the most vulnerable species. Low DO also significantly increased respiration rates of $A$. irradians and $M$. mercenaria, evidencing a compensatory physiological response to hypoxia. $M$. edulis and $M$. mercenaria both displayed size-dependent vulnerability to acidification, with smaller individuals being more susceptible. The combination of low DO and low pH often interacted antagonistically to yield growth rates higher than would be predicted from either individual stressor, potentially suggesting that some anaerobic metabolic pathways may function optimally under hypercapnia. Elevated temperature and low pH interacted both antagonistically and synergistically, producing outcomes that could not be predicted from the responses to individual stressors. Collectively, this study revealed species- and size-specific vulnerabilities of bivalves to coastal stressors along with unpredicted interactions among those stressors.
\end{abstract}

KEY WORDS: Bay scallops - Eastern oysters - Blue mussels - Hard clams - Ocean acidification · Dissolved oxygen $\cdot$ Ocean warming $\cdot$ Climate change $\cdot$ Synergy

\section{INTRODUCTION}

Earth's climate is changing. Atmospheric $\mathrm{CO}_{2}$ levels have risen from preindustrial levels of $\sim 280 \mathrm{ppm}$ to over $410 \mathrm{ppm}$ today, concentrations that have not been measured on this planet for over a million years (Lüthi et al. 2008, Doney et al. 2009). Elevated $p \mathrm{CO}_{2}$ has, in turn, lowered ocean $\mathrm{pH}, \mathrm{CO}_{3}{ }^{2-}$ levels, and $\mathrm{CaCO}_{3}$ saturation states, a process known as ocean acidification (Doney et al. 2009, 2012). Rising $\mathrm{CO}_{2}$ levels in the atmosphere have concurrently led to higher ocean temperatures that have, in turn, de-

${ }^{*}$ Corresponding author:

christopher.gobler@stonybrook.edu pressed ocean oxygen levels (Keeling et al. 2010, Doney et al. 2012). These changes to ocean temperatures and chemistry are influencing the physiology, behavior, size, distribution, and abundance of marine life (Doney et al. 2012).

Beyond climate change, cultural eutrophication is also changing coastal oceans as roughly $40 \%$ of the world's population lives within $100 \mathrm{~km}$ of coastlines (Martínez et al. 2007). Anthropogenic processes within coastal watersheds can deliver excessive nutrients to coastal waters, promoting the formation of algal blooms (Nixon 1995). The microbial decay of

(C) The authors 2018. Open Access under Creative Commons by Attribution Licence. Use, distribution and reproduction are unrestricted. Authors and original publication must be credited. 
this enhanced productivity increases community respiration and can create hypoxia (Diaz \& Rosenberg 2008), a condition that is stressful for marine organisms that may live within or near oxygen-depleted regions and has become more common since the mid- $20^{\text {th }}$ century (Diaz \& Rosenberg 2008, Rabalais et al. 2010). Sessile organisms, such as bivalves, which have limited mobility are particularly vulnerable to hypoxic events (Diaz \& Rosenberg 1995, Levin et al. 2009). Rising coastal temperatures can compound the intensity of hypoxia by both lowering gas solubility and increasing stratification, thereby reducing mixing and ventilation throughout the water column (Keeling et al. 2010, Doney et al. 2012).

Like hypoxia, acidification is also promoted by both climate change and eutrophication. Eutrophication contributes to coastal ocean acidification since enhanced respiration of algal organic matter leads to increased levels of $\mathrm{pCO}_{2}$ and decreased $\mathrm{pH}$ and aragonite saturation states $\left(\Omega_{\mathrm{Ar}}\right)$ (Feely et al. 2010, Cai et al. 2011, 2017, Wallace et al. 2014, Baumann \& Smith 2018). These changes in carbonate chemistry can inhibit the ability of calcifying organisms to produce an exoskeleton and can have other cascading effects on early life stage bivalves, including slowed growth and mortality (Talmage \& Gobler 2010, Gazeau et al. 2013, Waldbusser et al. 2013).

Filter feeding bivalves are an essential component of coastal ecosystems and are considered ecosystem engineers for their ability to mitigate eutrophication (Officer et al. 1982), improve light availability (Wall et al. 2008), recycle nutrients and organic matter (Dame 1996, Carroll et al. 2008), and overall make coastal ecosystems less susceptible to algal blooms (Cerrato et al. 2004, Gobler et al. 2005). Benthic filter feeders are also a critical food source for many organisms, including humans, supporting more than US\$1 billion in annual fisheries landings in the USA alone (Cooley \& Doney 2009, Ekstrom et al. 2015). Historically, coastal regions have supported large populations of ecologically and commercially important bivalve species (Newell 2004, Beck et al. 2011). However, most commercially valuable bivalves live within shallow estuaries and lagoons that are vulnerable to thermal stress (Pörtner 2010, Baumann \& Doherty 2013), hypoxia (Diaz \& Rosenberg 2008), and acidification (Wallace et al. 2014) threatening the sustainability of these populations (Beck et al. 2011).

The combined anthropogenic processes that increase $p \mathrm{CO}_{2}$ in coastal zones can create conditions unfavorable for calcification and general bivalve metabolism (Salisbury et al. 2008, Wallace et al. 2014, Ekstrom et al. 2015). Bivalves exposed to low oxygen conditions are vulnerable to slowed growth and mortality (Diaz \& Rosenberg 1995, Breitburg 2002, Levin et al. 2009), especially during early life stages (Zhang et al. 2010, Gobler et al. 2014), due to a greater amount of metabolic energy spent on adaptive biological processes including anaerobic metabolism (Wu 2002). Warming temperatures may increase the metabolic rate of some marine organisms, and their growth can be reduced by the stress of the warming environment (Pörtner 2008, 2010). Given that these environmental changes are occurring in unison, their collective impacts must be understood.

Multiple stressors in coastal environments, such as warming, hypoxia, and thermal stress, can interact in unpredictable ways. In broad terms, multiple stressors may yield outcomes that are additive or that may interact to cause impacts more or less intense than the simple addition of the stressors, outcomes deemed synergistic or antagonistic, respectively. In a broad meta-analysis of marine systems, Crain et al. (2008) found that environmental stressors were more likely to act synergistically or antagonistically than additively. They further found that the addition of a third stressor significantly changed interactive effects in two-thirds of studies, doubling the number of synergistic interactions (Crain et al. 2008) and indicating that synergies may be common in ecosystems where multiple stressors are present (Boyd et al. 2015). Regarding physiological effects, concurrent stressors such as hypoxia, warming, and/or acidification can decrease an organism's aerobic scope, yielding metabolic depression (Pörtner 2008, 2010) and/or the initiation of anaerobic metabolism which can result in slowed growth and even mortality in cases of sustained negative aerobic scope (Sokolova 2013). Warming of oceans is tightly linked to declining oxygen levels, as metabolic rates and the oxygen demand of marine organisms typically increase in warmer waters that hold less dissolved oxygen (Pörtner 2010). Deutsch et al. (2015) suggested that marine populations may contract poleward if warmer, lower latitude regions no longer sustain oxygen levels to support their energetic needs. Studies of bivalves have revealed that acidification effects can intensify as waters warm beyond optimal levels (Talmage \& Gobler 2011, Range et al. 2014). Hypoxia coupled with acidification can have both additive and synergistically negative effects on early life bivalves (Gobler et al. 2014). Hence, as climate change proceeds, the coeffects and interactions of multiple stressors on ocean life must be understood, although presently, very little is known regarding the combined effects of warming, hypoxia, and acidification on juvenile bivalves. 
The goal of this study was to quantify how warmer temperatures, lower $\mathrm{pH}$, and lower dissolved oxygen (DO), individually and in combination, affect the shell growth, survival, and respiration of recently settled juvenile bivalves native to the Northwest Atlantic Ocean, specifically bay scallops Argopecten irradians, eastern oysters Crassostrea virginica, blue mussels Mytilus edulis, and hard clams Mercenaria mercenaria. Bivalves were exposed to levels of temperatures, $\mathrm{pH}$, and DO that have been seasonally documented in temperate zones. We hypothesized that juvenile bivalves experiencing concurrently warmer water temperature, lower $\mathrm{pH}$, and lower oxygen conditions will experience additively slower shell growth rates and increased mortality compared to those exposed to only 1 stressor.

\section{MATERIALS AND METHODS}

This study involved 4 North American species of juvenile bivalves under 2 oxygen conditions, $2 \mathrm{pH}$ levels, and 2 temperatures. The shell growth, survival, and respiration of juvenile bivalves were measured during 4 wk experiments during which temperature, salinity, DO, and pH were controlled and quantified daily. Experiments were performed with post-set (shell length 1.5-18 mm) juvenile bivalves obtained from the East Hampton Town (NY, USA) Shellfish Hatchery (Mercenaria mercenaria, Crassostrea virginica, Argopecten irradians) or collected from Shinnecock Bay, NY (Mytilus edulis).

The bivalve species studied differ with regard to life history traits and biogeography. Eastern oysters are found from Canada to the Gulf of Mexico and can live up to $20 \mathrm{yr}$ (Kennedy et al. 1996). Similarly, hard clams can also live 20 yr or more, and are abundant from Cape Cod to as far south as Florida (Kraeuter \& Castagna 2001). The geographic range of bay scallops extends from the Gulf of Mexico to Canada, and this species grows quickly compared to the other bivalves, breeding when they are 1 yr old and rarely living more than 2 yr (Shumway \& Parsons 2006). Lastly, the blue mussel is a colder-water species that in North America can be found from the Arctic to the Carolinas (Almada-Villela et al. 1982).

\section{Experimental design}

Each experiment involved 1 bivalve species, with similar designs for each experiment. Experiments were performed with multiple size/age cohorts for a given species at the Marine Science Center located on Stony Brook University's campus in Southampton, NY. Experiments were performed using 4 replicate 81 polyethylene vessels filled with filtered $(0.2 \mu \mathrm{m})$ seawater from eastern Shinnecock Bay, NY (salinity $\sim 30)$. For 1 set of experiments with $C$. virginica ( $\sim 5 \mathrm{~mm}$ in length), $A$. irradians $(\sim 2 \mathrm{~mm})$, and $M$. edulis $(\sim 5 \mathrm{~mm})$, differences in $\mathrm{pH}$ and DO only were examined, with 16 vessels placed in a single sea table maintained at an ideal temperature (see below) and 4 conditions established: normal $\mathrm{pH}\left(\mathrm{pH}_{\mathrm{T}}=\right.$ total scale; $~ 7.9)+$ normal DO ( 8.0 $\left.\mathrm{mg} \mathrm{l}^{-1}\right)$, low DO $\left(\mathrm{pH}_{\mathrm{T}}\right.$ $\sim 7.9$; DO $\left.\sim 2.0 \mathrm{mg} \mathrm{l}^{-1}\right)$, low $\mathrm{pH}\left(\mathrm{pH}_{\mathrm{T}} \sim 7.2\right.$; DO $\sim 8.0 \mathrm{mg}$ $\left.\mathrm{l}^{-1}\right)$, and low $\mathrm{pH}+$ low DO $\left(\mathrm{pH}_{\mathrm{T}} \sim 7.2\right.$; DO $\left.\sim 2.0 \mathrm{mg} \mathrm{l}^{-1}\right)$. These experiments were designed to mimic those previously published for M. mercenaria (Gobler et al. 2014). For a second set of experiments with C. virginica (1 large cohort, $18 \mathrm{~mm}$ ), $M$. edulis (1 large cohort, $\sim 12 \mathrm{~mm}$ ), M. mercenaria (2 cohorts, small: $\sim 4 \mathrm{~mm}$; large: $\sim 6 \mathrm{~mm}$ ), and $A$. irradians (2 cohorts; shell lengths $=$ small: $\sim 8 \mathrm{~mm}$, large: $\sim 14 \mathrm{~mm}$ ), experimental vessels were placed in sea tables maintained at ideal and elevated temperatures (details below) within which 2 levels of $\mathrm{pH}$ and DO were examined.

The goal of these experiments was to create conditions that were environmentally realistic, representing extremes in $\mathrm{pH}, \mathrm{DO}$, and temperature that develop seasonally today within temperate ecosystems as well as conditions that will be more common in the near future (Doney et al. 2012, Baumann et al. 2015). Given that conditions of low $\mathrm{pH}$, low DO, and high temperatures all develop and persist for a month or longer during summer (Melzner et al. 2013, Wallace et al. 2014, Baumann et al. 2015, Cai et al. 2017) when small juvenile bivalves first set within estuaries, the experiments reported here created an environmentally realistic match between the life stage of bivalves used here and the conditions that they may encounter. Low $\mathrm{pH}$ treatment represented acidified conditions with a pH of 7.2-7.5, which created conditions slightly unsaturated with respect to aragonite $(\Omega<1.0$; see Table 1$)$. Although this $\mathrm{pH}$ is lower than open ocean climate change scenarios (Doney et al. $2009,2012)$ it is within the range of levels seen in eutrophic estuaries during summer months, sometimes for more than $4 \mathrm{wk}$, the duration of experiments performed here (Melzner et al. 2013, Wallace et al. 2014, Baumann et al. 2015, Cai et al. 2017) and represents a level that is marginally stressful to the species of juvenile bivalves used in the experiments presented here (Berge et al. 2006, Thomsen \& Melzner 2010, Waldbusser et al. 2010, Talmage \& Gobler 2011). The low DO treatment represented 
estuarine hypoxic conditions $\left(2-3 \mathrm{mg} \mathrm{l}^{-1}\right)$ that would be stressful but not lethal for the bivalves used in the experiments presented here (Stickle et al. 1989, Grizzle et al. 2001, Breitburg et al. 2003). Lastly, in each experiment, the bivalves were incubated at their ideal temperature as well as at an elevated temperature $\left(+6-7^{\circ} \mathrm{C}\right)$, a level that would be physiologically stressful (Almada-Villela et al. 1982, Kennedy et al. 1996, Grizzle et al. 2001, Shumway \& Parsons 2006) and similar to summer heat wave conditions in the Northeast USA (Nixon et al. 2004, Baumann \& Doherty 2013). Hard clams, bay scallops, and Eastern oysters were specifically grown at an ideal temperature of $24^{\circ} \mathrm{C}$ (Kennedy et al. 1996, Grizzle et al. 2001, Shumway \& Parsons 2006) and elevated temperature of $29-31^{\circ} \mathrm{C}$, whereas blue mussels were grown at an ideal temperature of $20^{\circ} \mathrm{C}$ (Almada-Villela et al. 1982) and at $26^{\circ} \mathrm{C}$. Sea tables were filled with water that was circulated via a water pump to ensure even temperatures for all experimental vessels. Heating wands (Finnex Aquarium Heater) were used to achieve desired temperatures. The target temperatures were monitored daily using a YSI 600QS sonde.

The control, normal $\mathrm{pH}$, normal DO conditions were aerated with ambient air to yield $\mathrm{pH}$ and $\mathrm{DO}$ levels of $\sim 7.9$ and $\sim 8 \mathrm{mg} \mathrm{l}^{-1}$, respectively. The low DO condition was achieved via bubbling with $400 \mathrm{ppm}$ $\mathrm{CO}_{2} / \mathrm{N}_{2}$ mixed gas and ambient air (Gobler et al. 2014). Low pH was achieved via bubbling with $5 \%$ $\mathrm{CO}_{2}$ gas and ambient air. The low $\mathrm{pH} /$ lowDO condition was achieved via bubbling with $5 \% \mathrm{CO}_{2}, \mathrm{~N}_{2}$ gas, and ambient air, preventing the hypoxic and basification associated with only bubbling $\mathrm{N}_{2}$ gas (Gobler et al. 2014). The supply of gas entering experimental vessels was regulated by Cole-Parmer ${ }^{\circledR}$ gas proportioners and delivered through a plastic airline (Tygon) connected to a glass-bonded silica air stone to provide even gas distribution throughout the vessels. All gas mixtures were delivered at a rate $(500 \mathrm{ml}$ $\mathrm{min}^{-1}$ ) that turned over the full volume of the experimental vessels several times per day. Experiments persisted for approximately $4 \mathrm{wk}$, representing the approximate duration of hypoxic, acidified, warm conditions in temperate zone summers (Breitberg et al. 2009, Wallace et al. 2014, Baumann et al. 2015, Baumann \& Smith 2018).

\section{Organisms}

Experiments were performed with small, post-set juvenile bivalves that can be vulnerable to environmental stressors (Green et al. 2009, Pörtner 2010).
Specifically, at the start of the experiments sizes of hard clams, eastern oysters, bay scallops, and blue mussels were varied from $\sim 1.5$ to $\sim 19 \mathrm{~mm}$, and the number of bivalves per replicate 81 bucket $(\mathrm{n}=4)$ varied between 5 and 15 individuals with more of smaller individuals $(n=15)$ and fewer of larger individuals $(n=5)$. A subset of the cohort of bivalves used in experiments was set aside and dry tissue weights per individual were quantified. Individuals within this subset were shucked and the tissue was removed and placed in previously weighed tins. The tissue was then placed in a drying oven $\left(\sim 65^{\circ} \mathrm{C}\right)$ for $1 \mathrm{wk}$ and then re-weighed using a Scientech $®$ microbalance $( \pm 0.1 \mathrm{mg})$ yielding a tissue weight. Experimental bivalves were fed $5 \%$ of their dry tissue weights in algae daily, using a mixed algal species diet of $50 \%$ Isochrysis galbana (Tahitian strain), $15 \%$ Tetraselmis suecica, $15 \%$ T. chuii, and $20 \%$ Pavlova lutheri based on cell densities (Helm et al. 2004). Prior to experiments, individuals were maintained in flow through-water at $\sim 20^{\circ} \mathrm{C}$ (for mussels) or $\sim 24^{\circ} \mathrm{C}$ (for clams, scallops, and oysters) for at least $72 \mathrm{~h}$. Individuals exposed to elevated water temperature for experiments experienced slowly raised temperatures over $24 \mathrm{~h}$ prior to the start of experiments.

\section{Water chemistry and physical conditions}

Temperature and salinity were measured daily with a YSI 600QS sonde, while $\mathrm{pH}$ was measured daily with a Honeywell Durafet Ion Sensitive Field Effect Transistor (ISFET)-based $\mathrm{pH}$ sensor (total scale) calibrated with a seawater $\mathrm{pH}$ standard (Dickson 1993). This device yields $\mathrm{pH}$ measurements consistent with levels measured using spectrophotometric techniques (Gobler et al. 2014). Oxygen was measured via a YSI 5100 oxygen meter with a Clark electrode. This device yields DO measurements consistent with levels measured using wet chemical techniques (i.e. Winkler titrations; Gobler et al. 2014).

At the beginning and end of each experiment, dissolved inorganic carbon (DIC) analyses of experimental water were conducted to define the carbonate chemistry present during experiments. DIC was measured by using a Liqui-Cel-@ Membrane (Membrana) to separate gaseous DIC from acidified seawater. Next, the gaseous DIC was quantified by an Environmental Gas Analyzer® (EGM-4), an infrared-based $\mathrm{CO}_{2}$ detection system. The EGM was calibrated with sodium bicarbonate standards at the beginning and end of each analytical run. To determine the precision and accuracy of this technique, Dr. 
Andrew Dickson's (University of California San Diego, Scripps Institution of Oceanography) certified reference material (CRM) for DIC was analyzed in triplicate during each analytic run, with sample analyses only proceeding if complete recovery (100 \pm $5 \%$ ) of CRM was achieved. DIC levels, along with $\mathrm{pH}$, temperature, salinity, pressure, phosphate, silicate, and carbonic acid dissociation constants recommended for estuarine waters (Millero 2010) were analyzed with the CO2SYS program (http://cdiac. ornl.gov/ftp/co2sys/) in order to quantify levels of $p \mathrm{CO}_{2}, \Omega_{\text {calcite, }} \Omega_{\text {aragonite, carbonate, and total alkalinity. }}$

\section{Water changes and mortality}

The survival of individuals in all experimental vessels was monitored daily. Individuals within buckets were considered dead if their shells were visibly open, were easily opened upon removal, and/or lacked response (i.e. shutting of shell); dead individuals were removed immediately. Water within experimental vessels was changed twice a week when individuals were removed, and experimental vessels were liberally rinsed with deionized water and refilled with new filtered seawater and algae as described above.

\section{Growth rates and weights}

An initial, mean cohort size and dry tissue weight was determined by randomly measuring 50 juveniles before starting the experiment to quantify their initial shell length and dry tissue weight. This initial tissue weight was used to determine the dry tissue weight of the cohort and the volume of algae necessary to feed the bivalves as described above (Helm et al. 2004). Each bivalve $>5 \mathrm{~mm}$ was tagged with Bee Tags (Hallprint Fish Tags) to determine individual shell growth rates; growth rates for smaller individuals were determined as a mean per replicate bucket, whereas individual growth rates were averaged when tags were used. Lengths of individuals were determined at the start of the experiment and at $4 \mathrm{wk}$. All bivalve lengths were measured with digital calipers (Mitutoyo 500-784 Absolute Digital Caliper) from posterior to anterior end of the shell. Growth rates were calculated using the equation: $\mathrm{GR}=$ $\left(L_{2}-L_{1}\right) /\left(t_{2}-t_{1}\right)$ where GR is the absolute growth rate (per day), $L_{2}$ and $L_{1}$ represent the final and initial length in $\mathrm{mm}$, and $t_{2}$ and $t_{1}$ represent the final and initial time (days) (Grizzle et al. 2001). The dry tissue weights of juvenile bivalves were quantified at the end of the experiment with all surviving bivalves as described above.

\section{Respiration}

For 2 experiments, (i.e. small juvenile Argopecten irradians and small juvenile Mercenaria mercenaria) the respiration rates of individuals were measured after 2 and 4 wk of exposure to experimental conditions, and later averaged into a mean of both time points. A PyroScience ${ }^{\circledR}$ Firesting $_{2}$ Optical Oxygen Sensor was used to quantify changes in oxygen levels within $20 \mathrm{ml}$ respiration vials. The vials were slowly and completely filled with water from the specific treatment without bubbling, and individuals from the treatment were carefully transferred via tweezers to each vial. The Pyro Oxygen Logger recorded oxygen levels within vials every second of the duration of the incubations with the $A$. irradians incubations persisting for $1 \mathrm{~h}$ and $M$. mercenaria incubations being for $2 \mathrm{~h}$. This time frame provided near-linear declines in DO and ensured that DO levels never declined by more than $50 \%$ during the incubations. For every treatment within the experiment, 1 individual from each replicate bucket $(n=4)$ per treatment was randomly selected and analyzed simultaneously on the 4 channels of the Firesting $\mathrm{O}_{2}$. Respiration rates were calculated via the change in DO and dry tissue weight and were expressed as mg $\mathrm{O}_{2} g$ dry weight ${ }^{-1} \mathrm{~h}^{-1}$.

\section{Statistical analysis}

All statistical analyses were performed using R-® software (version: 1.0.44; www.r-project.org). Twoway analysis of variance (ANOVA) tests were used to assess the response of shell growth and survival of juvenile bivalves during experiments where $\mathrm{pH}$ and DO levels were the 2 main treatment factors. When temperature was added as an experimental variable, 3-way ANOVAs were used to assess the response of shell growth, survival, tissue weights, and respiration rates of juvenile bivalves during each experiment where temperature, $\mathrm{pH}$, and DO levels were the main treatment factors. For the ANOVAs, the survival datasets were modeled using generalized linear models (GLMs) with either a binomial or gamma error structure in response to the treatments to account for the uneven design due to mortality of individuals. Binomial error structures were used for proportional data sets like survival (i.e. fraction of alive or dead). 
Two-way ANOVAs assessing shell growth rates and tissue weights (i.e. Argopecten irradians and Crassostrea virginica) were modeled using a linear model (LM) with a Gaussian error structure in response to the treatments. Normality and equal variance were confirmed prior to analyses with the Shapiro-Wilk and Levene's tests. Datasets that did not follow a Gaussian error structure (i.e. Mytilus edulis) were modeled with a GLM using a gamma structure prior to ANOVA. All respiration data sets were analyzed using a GLM with a gamma error structure.

All ANOVAs were tested for isolated effects of the treatments, as well as the interactions of the respective treatments. Statistically significant interactions were deemed antagonistic when a combined treatment of 2 factors had a lesser than additive effect, whereas outcomes within dual treatments greater than additive were deemed synergistic. Percent survival data were arc-sin square root transformed prior to statistical analyses. Log transformation to increase normality was also performed on several shell growth rate and tissue weight datasets that were right-skewed, prior to analysis for linear models. LMs and GLMs were generated using the 'anova' function in $\mathrm{R}$, with a significance threshold of $\alpha=0.05$. LM fitted models were tested for normality and equal variance. Normality tests were implemented using the Shapiro-Wilk test and equal variance tests were executed via Bartlett and Levene's tests, and the goodness of fit of the GLM was assessed using 1 - (residual deviance / null deviance).

\section{RESULTS}

\section{Effects of low DO and low pH}

\section{Argopecten irradians}

Low DO significantly reduced the survival of juvenile scallops $(1.58 \pm 0.39 \mathrm{~mm})$, while low $\mathrm{pH}$ did not $(\mathrm{p}<0.0001 ; 2$-way ANOVA; Table 1, Fig. 1A; see

Table 1. Statistical significance of main effects and interactions among environmental factors examined in the 9 experiments presented in this manuscript. Initial shell lengths represent means \pm SD. P-values in bold for main effects indicate a positive effect of the factor on the bivalve trait, whereas normal text is a negative effect; and p-values in bold for interactions indicate an antagonistic effect, whereas normal text is a synergistic effect. DO: dissolved oxygen; ns: not significant

\begin{tabular}{|c|c|c|c|c|c|c|c|c|c|}
\hline \multirow[t]{2}{*}{ Bivalve } & \multirow{2}{*}{$\begin{array}{l}\text { Initial shell } \\
\text { length (mm) }\end{array}$} & \multirow[t]{2}{*}{ Parameter } & \multirow[b]{2}{*}{ DO } & \multirow{2}{*}{$\begin{array}{c}\text { Main effects } \\
\text { pH }\end{array}$} & \multirow{2}{*}{ Temp. } & \multirow[b]{2}{*}{$\begin{array}{c}\mathrm{DO} \times \\
\mathrm{pH}\end{array}$} & \multicolumn{2}{|c|}{ Interactions } & \multirow[b]{2}{*}{$\begin{array}{l}\mathrm{DO} \times \mathrm{pH} \\
\times \mathrm{Temp}\end{array}$} \\
\hline & & & & & & & $\begin{array}{l}\text { DO } \times \\
\text { Temp. }\end{array}$ & $\begin{array}{l}\mathrm{pH} \times \\
\text { Temp. }\end{array}$ & \\
\hline \multirow{9}{*}{$\begin{array}{c}\text { Argopecten } \\
\text { irradians }\end{array}$} & \multirow[t]{2}{*}{$1.58 \pm 0.39$} & Survival & $<0.0001$ & ns & - & $<0.05$ & - & - & - \\
\hline & & Growth rate & $<0.0001$ & ns & - & $<0.05$ & - & - & - \\
\hline & \multirow[t]{4}{*}{$7.92 \pm 0.87$} & Survival & $<0.0001$ & $<0.0001$ & $<0.01$ & ns & ns & $<0.05$ & ns \\
\hline & & Growth rate & ns & ns & ns & ns & ns & ns & ns \\
\hline & & Weight & ns & ns & ns & ns & ns & ns & ns \\
\hline & & Respiration & $<0.0001$ & ns & ns & ns & ns & ns & ns \\
\hline & \multirow[t]{3}{*}{$13.71 \pm 0.78$} & Survival & $<0.05$ & $<0.0001$ & $<0.0001$ & $<0.01$ & ns & ns & ns \\
\hline & & Growth rate & ns & ns & $<0.05$ & $\mathrm{~ns}$ & ns & ns & ns \\
\hline & & Final weights & ns & ns & $<0.01$ & ns & ns & ns & ns \\
\hline \multirow{5}{*}{$\begin{array}{c}\text { Crassostrea } \\
\text { virginica }\end{array}$} & \multirow[t]{2}{*}{$4.46 \pm 0.51$} & Survival & ns & ns & - & ns & - & - & - \\
\hline & & Growth rate & $<0.001$ & ns & - & $<0.01$ & - & - & - \\
\hline & \multirow[t]{3}{*}{$18.62 \pm 1.27$} & Survival & $<0.01$ & ns & $<0.05$ & $<0.05$ & ns & ns & ns \\
\hline & & Growth rate & ns & $<0.05$ & ns & ns & ns & ns & ns \\
\hline & & Weight & $<0.05$ & ns & $<0.0001$ & ns & ns & ns & ns \\
\hline \multirow[t]{5}{*}{ Mytilus edulis } & \multirow{2}{*}{$5.39 \pm 0.68$} & Survival & ns & $<0.05$ & - & ns & - & - & - \\
\hline & & Growth rate & $<0.0001$ & ns & - & $<0.0001$ & - & - & - \\
\hline & \multirow[t]{3}{*}{$12.33 \pm 1.23$} & Survival & ns & ns & ns & ns & ns & ns & ns \\
\hline & & Growth rate & ns & ns & $<0.0001$ & ns & ns & ns & ns \\
\hline & & Weight & ns & ns & $<0.05$ & $<0.05$ & ns & ns & ns \\
\hline \multirow{7}{*}{$\begin{array}{l}\text { Mercenaria } \\
\text { mercenaria }\end{array}$} & \multirow[t]{4}{*}{$3.97 \pm 0.41$} & Survival & ns & $<0.05$ & $<0.0001$ & $<0.01$ & $<0.001$ & $<0.01$ & ns \\
\hline & & Growth rate & ns & $<0.0001$ & ns & ns & ns & ns & ns \\
\hline & & Weight & ns & $<0.0001$ & $<0.001$ & ns & ns & ns & ns \\
\hline & & Respiration & $<0.0001$ & ns & ns & ns & ns & $<0.05$ & ns \\
\hline & \multirow[t]{3}{*}{$6.11 \pm 0.80$} & Survival & $<0.0001$ & ns & $<0.0001$ & ns & ns & $<0.05$ & ns \\
\hline & & Growth rate & $<0.05$ & ns & $<0.0001$ & ns & ns & $<0.01$ & ns \\
\hline & & Weight & ns & ns & ns & ns & ns & ns & ns \\
\hline
\end{tabular}



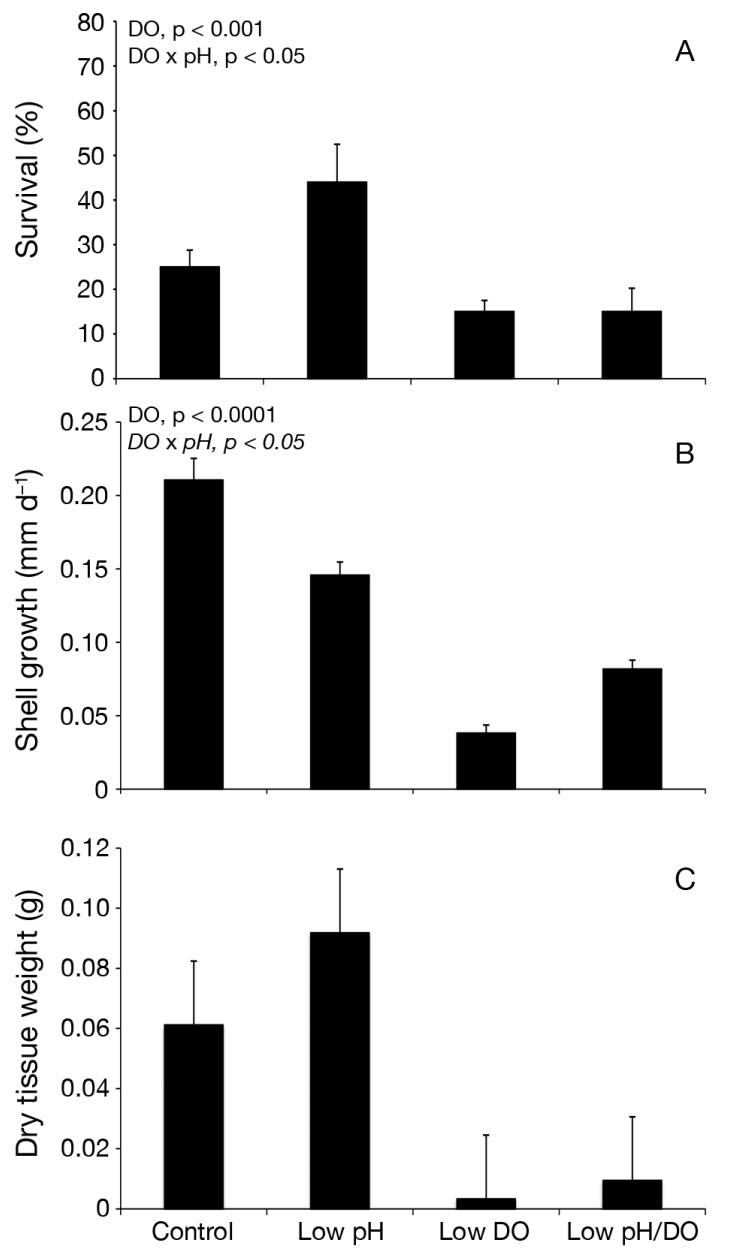

Fig. 1. (A) Survival, (B) shell growth, and (C) dry tissue weight of Argopecten irradians exposed to low $\mathrm{pH}$ and low DO. Initial shell length was $1.58 \pm 0.39 \mathrm{~mm}$. Shell lengthbased growth rates and tissue weights were measured after a $28 \mathrm{~d}$ period. Dry tissue weights are pooled data for all individuals in each replicate $(\mathrm{n}=15)$. Bars represent the mean $(n=4)$ for each treatment. Error bars represent SE $(n=4)$. Significant main effects and interactions appear in the upper left corner of each graph. Italics for the DO $\times \mathrm{pH}$ interaction indicate an antagonistic interaction. Experimental conditions appear in Table S1, and statistics are presented in Tables S2 \& S3, in the Supplement

Tables S1 \& S2 in the Supplement at www.int-res. com/articles/suppl/m604p143_supp.pdf). Survival was lowest $(15 \%)$ in the low DO (DO $=1.932 \pm$ $0.82 \mathrm{mg} \mathrm{l}^{-1}$; mean $\left.\pm \mathrm{SD}\right)$ and low $\mathrm{pH} /$ low DO $\left(\mathrm{pH}_{\mathrm{T}}=\right.$ $7.441 \pm 0.15 ; \mathrm{DO}=2.391 \pm 1.45 \mathrm{mg} \mathrm{l}^{-1}$ ) treatments, whereas survival under low $\mathrm{pH}\left(\mathrm{pH}_{\mathrm{T}}=7.496 \pm 0.04\right.$; $\mathrm{DO}=8.555 \pm 0.82 \mathrm{mg} \mathrm{l}^{-1}$ ) was more than twice as high compared to the low DO and low pH/low DO treatments $(\sim 35 \%$; Fig. $1 \mathrm{~A})$. There was also an interactive, synergistic effect of DO and $\mathrm{pH}$ on survival, whereby scallop survival was lower than would have been predicted based on survival in the singular treatments ( $\mathrm{p}<0.05$; Fig. 1A).

Low DO also significantly reduced the shell growth of juvenile scallops $(\mathrm{p}<0.0001)$ to $0.038 \pm 0.011 \mathrm{~mm}$ $\mathrm{d}^{-1}$ compared to the control $\left(0.211 \pm 0.029 \mathrm{~mm} \mathrm{~d}^{-1}\right)$ and while low $\mathrm{pH}$ did not significantly alter shell growth, there was a significant interaction between $\mathrm{pH}$ and DO as the combined treatment had a higher shell growth rate than the low DO treatment $(0.0817$ $\pm 0.012 \mathrm{~mm} \mathrm{~d}^{-1} ; \mathrm{p}<0.05 ; 2$-way ANOVA; Table 1, Fig. 1B; Tables S1 \& S3). Paralleling survival and length-based shell growth, tissue weights of scallops were reduced in the low DO treatments from a mean of $77 \pm 21.6 \mathrm{mg}$ ind. ${ }^{-1}$ for the high DO treatments to a mean of $6 \pm 4.31 \mathrm{mg}$ ind. ${ }^{-1}$ under low DO (Table 1, Fig. 1C; Table S1).

\section{Crassostrea virginica}

Neither $\mathrm{pH}$ nor DO altered survival rates of juvenile oysters (4.46 $\pm 0.51 \mathrm{~mm}$; Fig. 2A; Table S6). Low DO $\left(1.98 \pm 0.51 \mathrm{mg} \mathrm{l}^{-1}\right)$ significantly reduced the shell growth of juvenile oysters to $0.126 \pm 0.02 \mathrm{~mm} \mathrm{~d}^{-1}$ relative to the control $\left(\sim 0.18 \mathrm{~mm} \mathrm{~d}^{-1}\right.$; $\mathrm{p}<0.001$; 2-way ANOVA; Table 1, Fig. 2B; Tables S4 \& S5), with pH and DO $\left(\mathrm{pH}_{\mathrm{T}}=7.195 \pm 0.05 ; \mathrm{DO}=2.021 \pm 0.39 \mathrm{mg} \mathrm{l}^{-1}\right)$ interacting to yield higher shell growth rates than would be expected by the singular low $\mathrm{pH}$ and DO treatments $(\mathrm{p}<0.01$; 2 -way ANOVA; Table 1, Fig. 2B; Table S5). Tissue weights of oysters were reduced in the low DO treatments from a mean of $208 \pm 5.80 \mathrm{mg}$ ind. ${ }^{-1}$ for the high DO treatments to a mean of $170 \pm$ $20.2 \mathrm{mg} \mathrm{ind}^{-1}$ (Fig. 2C).

\section{Mytilus edulis}

While juvenile mussels $(5.39 \pm 0.68 \mathrm{~mm})$ in control and low DO treatments experienced $100 \%$ survival throughout the experiment, survival was slightly, but significantly, lower in the lower pH treatments (98\%; $\mathrm{p}<0.05$; 2-way ANOVA; Table 1, Fig. 3A; Tables S7 $\&$ S8). In contrast, shell growth rates of mussels were unaffected by low $\mathrm{pH}$ but were significantly reduced in the low DO treatments from $0.164 \pm 0.01 \mathrm{~mm} \mathrm{~d}^{-1}$ in the control to $0.00983 \pm 0.002$ and $0.0217 \pm 0.01 \mathrm{~mm}$ $\mathrm{d}^{-1}$ in the low DO $\left(1.842 \pm 1.29 \mathrm{mg} \mathrm{l}^{-1}\right)$ and the low $\mathrm{pH} /$ low DO $\left(\mathrm{pH}_{\mathrm{T}}=7.31 \pm 0.05 ; \mathrm{DO}=2.23 \pm 0.52 \mathrm{mg}\right.$ $\left.\mathrm{l}^{-1}\right)$ treatments $(\mathrm{p}<0.0001 ; 2$-way ANOVA; Fig. 3B; Tables S7 \& S9). There was again a significant $\mathrm{pH}-$ DO interaction as the combined low pH/low DO treatment yielded higher shell growth rates than the 

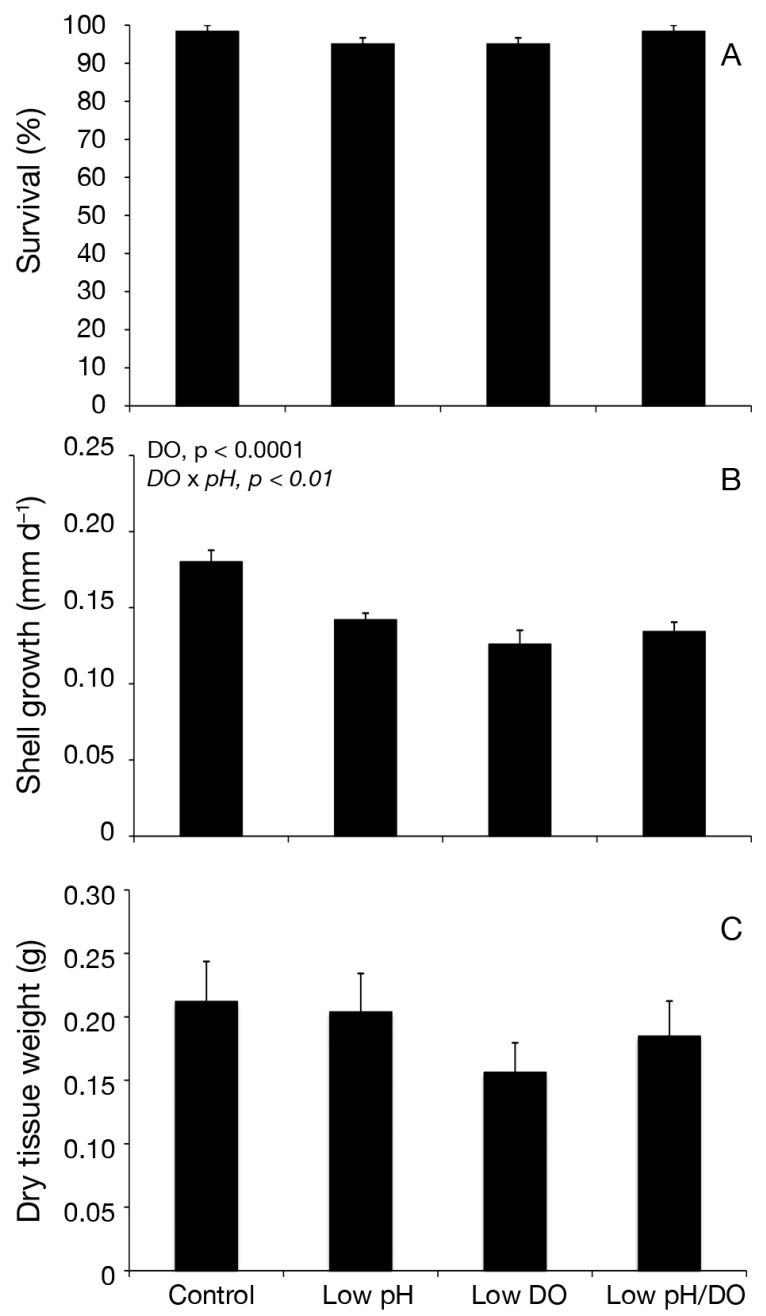

Fig. 2. (A) Survival, (B) shell growth, and (C) dry tissue weight of Crassostrea virginica exposed to low $\mathrm{pH}$ and low DO. Initial shell length was $4.46 \pm 0.51 \mathrm{~mm}$. Shell lengthbased growth rates and tissue weights were measured after a $28 \mathrm{~d}$ period. Other details as in Fig. 1. Experimental conditions appear in Table S4, and statistics are presented in Tables S5 \& S6

low DO treatment alone $(\mathrm{p}<0.0001 ; 2$-way ANOVA; Table 1, Fig. 3B; Tables S7 \& S9). Paralleling lengthbased shell growth, tissue weights of mussels were reduced in the low DO treatments from a mean of $296 \pm 0.01 \mathrm{mg}$ ind. ${ }^{-1}$ for the high DO treatments to a mean of $108 \pm 44.5 \mathrm{mg}$ ind..$^{-1}$ (Fig. 3C).

\section{Effects of low DO, low pH, and temperature}

\section{Mytilus edulis}

Juvenile $M$. edulis $(12.33 \pm 1.23 \mathrm{~mm})$ experienced high survival rates (93-100\%) during the 4 wk experi-
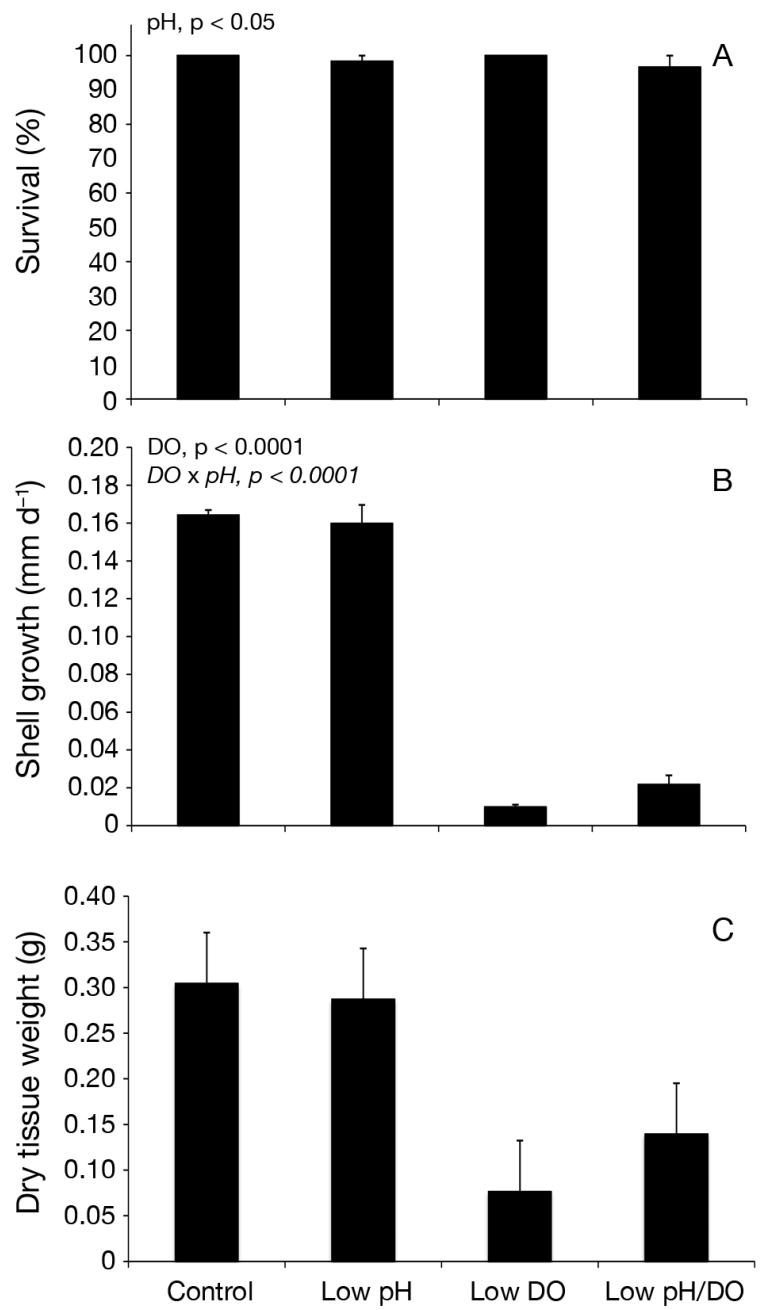

Fig. 3. (A) Survival, (B) shell growth, and (C) dry tissue weight of Mytilus edulis exposed to low $\mathrm{pH}$ and low DO. Initial shell length was $5.39 \pm 0.68 \mathrm{~mm}$. Shell length-based growth rates and tissue weights were measured after a $20 \mathrm{~d}$ period. Other details as in Fig. 1. Experimental conditions appear in Table S7, and statistics are presented in Tables S8 \& S9

ment that were unaffected by any of the treatments (Fig. 4A; Tables $\mathrm{S} 10$ \& S11). In contrast, elevated temperatures $\left(26^{\circ} \mathrm{C}\right)$ significantly reduced weights and shell growth rates by more than $50 \%(\mathrm{p}<0.05$ and $\mathrm{p}<$ 0.0001, respectively; 3 -way ANOVA; Table 1, Fig. 4B; Table S12). There was a significant, synergistic interaction between $\mathrm{DO}$ and $\mathrm{pH}$ with regard to the tissue weights of the juvenile mussels, with individuals exposed to both stressors being lighter than would be expected by the individual stressor $(\mathrm{p}<0.05$; 3 -way ANOVA $;$ Table 1, Fig. 4C; Table S13). Specifically, the combined low $\mathrm{pH} /$ low $\mathrm{DO}\left(\mathrm{pH}_{\mathrm{T}}=7.35 \pm 0.23 ; \mathrm{DO}=\right.$ $3.30 \pm 0.95 \mathrm{mg} \mathrm{l}^{-1}$ ) treatment yielded tissue weights at both temperatures that were lower than either of the individual treatments or the control (Fig. 4C). 

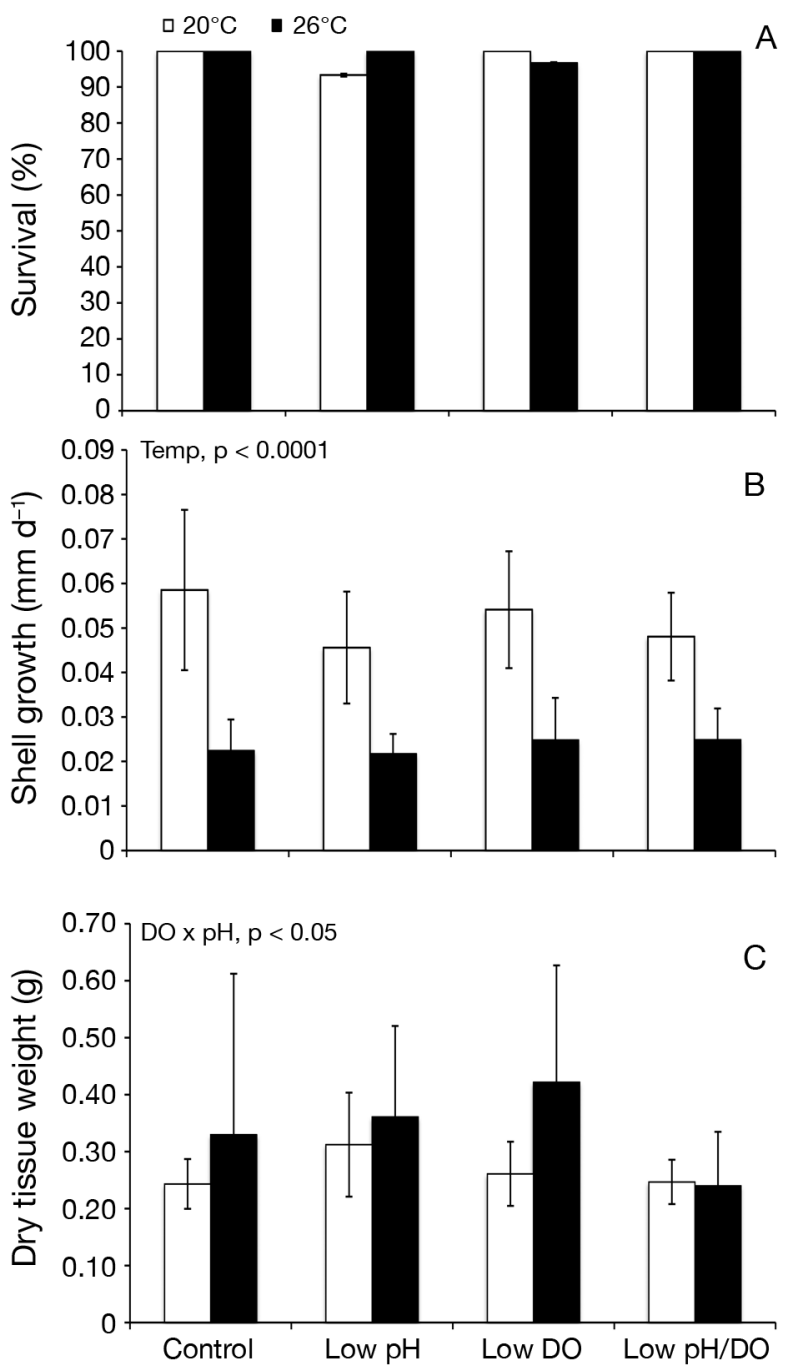

Fig. 4. (A) Survival, (B) shell growth, and (C) dry tissue weight of Mytilus edulis exposed to thermal stress, acidification, and hypoxia. Initial shell length was $12.33 \pm 1.23 \mathrm{~mm}$. Shell length-based growth rates and tissue weights were measured after a $32 \mathrm{~d}$ period. Dry tissue weights are pooled data for all individuals in each replicate $(n=5)$. Bars represent the mean $(n=4)$ for each treatment. Error bars represent SE $(n=4)$. Significant main effects and interactions appear in the upper left corner of each graph. $\mathrm{DO} \times \mathrm{pH}$ interaction was synergistic. Experimental conditions appear in Table S10, and statistics are presented in Tables S11-S13

\section{Crassostrea virginica}

Juvenile oyster $(18.62 \pm 1.27 \mathrm{~mm})$ survival was marginally but significantly lower in the warmer temperature treatment $\left(31^{\circ} \mathrm{C}\right)$ compared to the cooler temperature treatment $\left(24^{\circ} \mathrm{C}\right)(\mathrm{p}<0.05 ; 3$-way ANOVA; Table 1, Fig. 5A; Tables S14 \& S15). Low DO $\left(2.26 \pm 0.33 \mathrm{mg} \mathrm{l}^{-1}\right)$ also significantly reduced survival rates in juvenile oysters, although this was more pronounced at $31^{\circ} \mathrm{C}(73 \pm 3.59 \%$ survival $)$ compared to $24^{\circ} \mathrm{C}(98 \pm 0.5 \%$ survival; $\mathrm{p}<0.01$; 3 -way ANOVA; Table 1, Fig. 5A; Tables S14 \& S15). There was an antagonistic interaction between $\mathrm{pH}$ and $\mathrm{DO}$ on oyster survival, as when low DO was experienced concurrently with low $\mathrm{pH}$, the negative effects of low DO at $31^{\circ} \mathrm{C}$ vanished (Table 1, Fig. 5A; Table S15).

In contrast to survival, $\mathrm{pH}\left(\mathrm{pH}_{\mathrm{T}}=7.212 \pm 0.004\right)$ had a negative effect on length-based shell growth rates of juvenile $C$. virginica $(\mathrm{p}<0.05 ; 3$-way ANOVA; Table 1, Fig. 5B; Table S16). While shell growth rates among normocapnic $\mathrm{pH}$ treatments
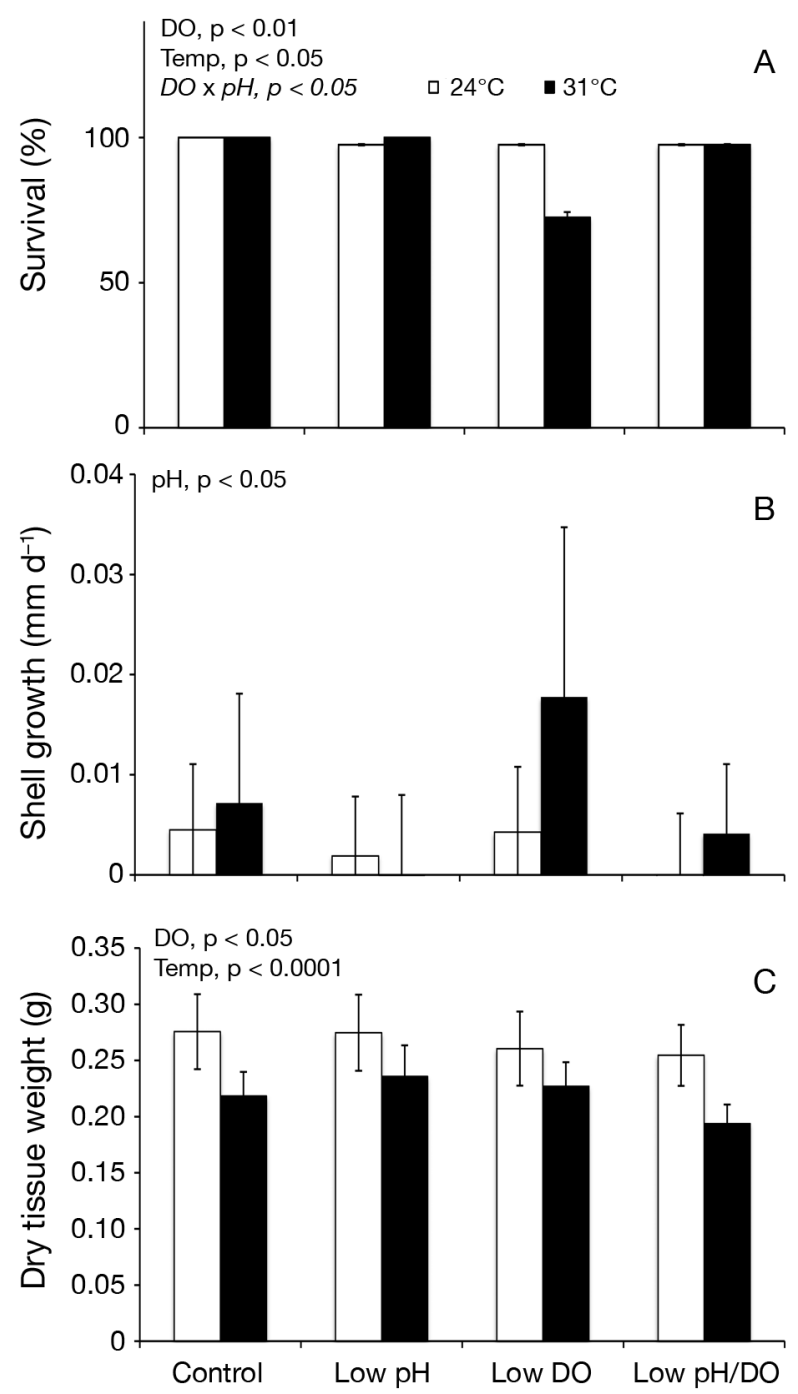

Fig. 5. (A) Survival, (B) shell growth, and (C) dry tissue weight of Crassostrea virginica exposed to thermal stress, acidification, and hypoxia. Initial shell length was $18.62 \pm$ $1.27 \mathrm{~mm}$. Shell length-based growth rates and tissue weights were measured after a $30 \mathrm{~d}$ period. Other details as in Fig. 4. Italics for the $\mathrm{DO} \times \mathrm{pH}$ interaction indicate an antagonistic interaction. Experimental conditions appear in Table S14, and statistics are presented in Tables S15-S17 
ranged from 0.005 to $0.02 \mathrm{~mm} \mathrm{~d}^{-1}$, rates were significantly reduced under low $\mathrm{pH}$ conditions, with individuals at $31^{\circ} \mathrm{C}$ under low $\mathrm{pH}$ and individuals at $24^{\circ} \mathrm{C}$ under low $\mathrm{pH}$ and low DO displaying no shellbased growth during the entire $4 \mathrm{wk}$ experiment (Fig. 5B). Regarding tissue weights of the juvenile oysters, individuals exposed to $31^{\circ} \mathrm{C}$ were significantly lighter than individuals grown at $24^{\circ} \mathrm{C}(\mathrm{p}<$ 0.0001; 3-way ANOVA; Fig. 5C; Table S17).

\section{Small juvenile Argopecten irradians}

Survival was significantly greater in the warmer temperature treatment $\left(30^{\circ} \mathrm{C}\right)$ compared to the colder temperature treatment $\left(24^{\circ} \mathrm{C}\right)$ for juvenile $A$. irradians $\left(7.92 \pm 0.87 \mathrm{~mm}_{i} \mathrm{p}<0.01\right.$ for each; 3-way ANOVA; Table 1, Fig. 6A; Tables S18 \& S19), whereas survival was significantly reduced by the low $\mathrm{pH}\left(\mathrm{pH}_{\mathrm{T}}=7.26 \pm 0.001\right)$ and low DO $(2.78 \pm 0.01$ $\mathrm{mg} \mathrm{l}^{-1}$ ) conditions ( $\mathrm{p}<0.0001$ for each; 3-way ANOVA; Table 1, Fig. 6A; Tables S18 \& S19). While control scallops with normal DO and $\mathrm{pH}\left(\mathrm{pH}_{\mathrm{T}}=\right.$ $7.83 \pm 0.01 ; \mathrm{DO}=6.34 \pm 0.56 \mathrm{mg} \mathrm{l}^{-1}$ ) exhibited $\sim 75 \%$ survival, survival under low $\mathrm{pH} /$ low DO $\left(\mathrm{pH}_{\mathrm{T}}=7.28 \pm\right.$ $0.08 ; \mathrm{DO}=2.64 \pm 0.31 \mathrm{mg} \mathrm{l}^{-1}$ ) treatment at $24^{\circ} \mathrm{C}$ was only $22 \pm 2.2 \%$ (Fig. $6 \mathrm{~A}$ ). There was a significant interaction between $\mathrm{pH}$ and temperature, whereby scallops exposed to $24^{\circ} \mathrm{C}$ and low $\mathrm{pH}\left(\mathrm{pH}_{\mathrm{T}}=7.258 \pm\right.$ 0.06) had lower than expected survival ( $\mathrm{p}<0.05$; 3-way ANOVA; Fig. 6A; Table S19). In contrast to survival, length-based shell growth rates and dried tissue weights did not differ significantly among treatments (Table 1, Fig. 6B,C; Tables S20 \& S21).

Respiration rates were significantly elevated by exposure to low DO treatments $(\mathrm{p}<0.0001$; 3-way ANOVA; Table 1, Fig. 6D; Table S22). After $2 \mathrm{wk}$, control and low $\mathrm{pH}$ treatments displayed rates of respiration (5.8-9.3 $\mathrm{mg} \mathrm{O}_{2} \mathrm{~g}_{\text {dry }}$ weight ${ }^{-1} \mathrm{~h}^{-1}$ ) that were significantly lower than individuals within the low DO and low pH/low DO treatments (9.5-17.6 mg $\mathrm{O}_{2}$ g dry weight ${ }^{-1} \mathrm{~h}^{-1}$; Table 1, Fig. $6 \mathrm{D}$; Table S22).

\section{Large juvenile Argopecten irradians}

While $100 \%$ of large juvenile scallops $(13.71 \pm$ $0.78 \mathrm{~mm})$ survived control conditions $\left(24^{\circ} \mathrm{C}, \mathrm{pH}_{\mathrm{T}}=\right.$ $7.80 \pm 0.04 ; \mathrm{DO}=6.43 \pm 0.31 \mathrm{mg} \mathrm{l}^{-1}$ ), higher temperature, lower $\mathrm{pH}$, or lower $\mathrm{DO}$ all significantly reduced their survival ( $\mathrm{p}<0.05$ for all; 3-way ANOVA; Table 1, Fig. 7A; Tables S23 \& S24). Survival was significantly higher in the colder temperature treatment $\left(24^{\circ} \mathrm{C}\right)$
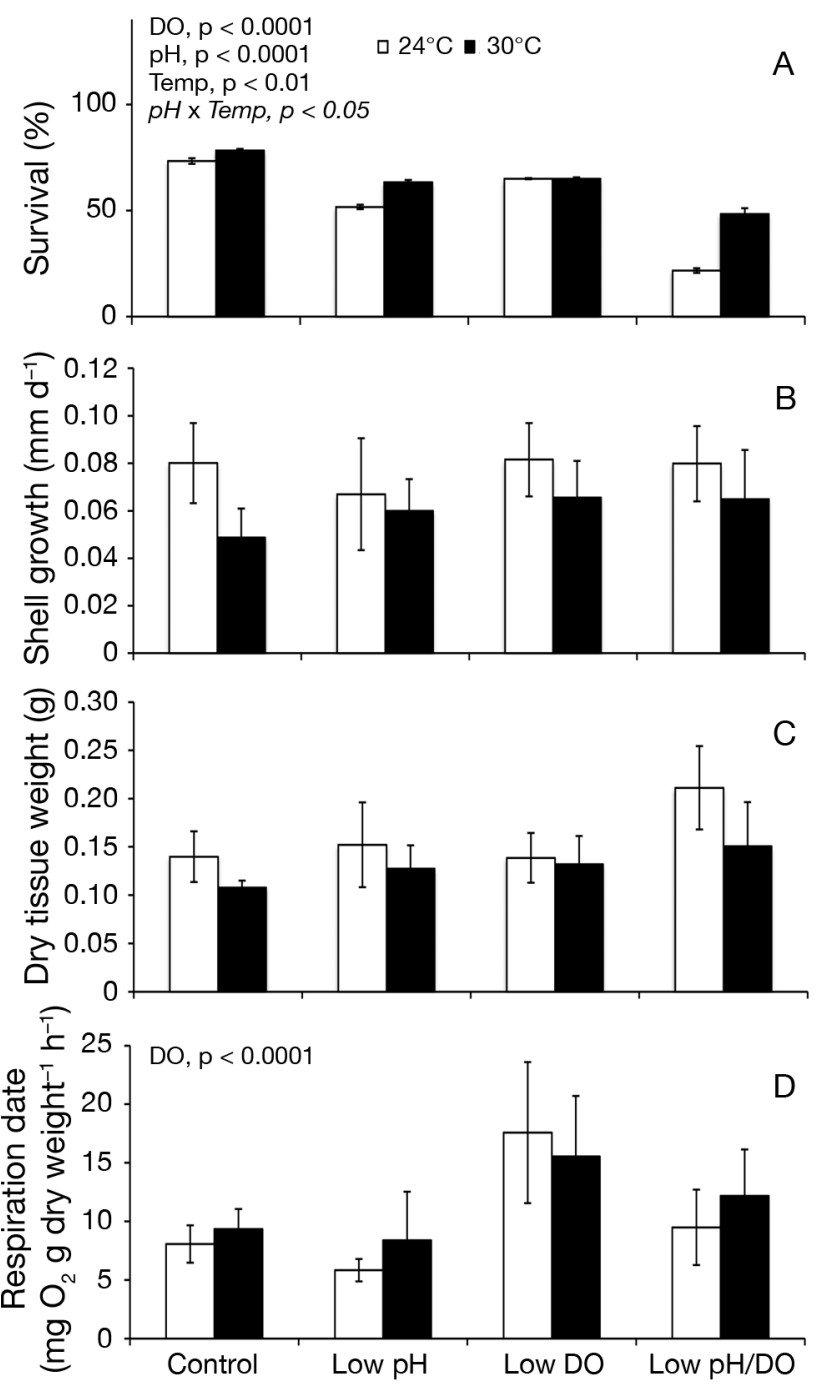

Fig. 6. (A) Survival, (B) shell growth, (C) dry tissue weight, and (D) respiration rates of smaller Argopecten irradians exposed to thermal stress, acidification, and hypoxia. Initial shell length was $7.92 \pm 0.87 \mathrm{~mm}$. Shell length-based growth rates and tissue weights were measured after a $25 \mathrm{~d}$ period. Dry tissue weights are pooled data for all individuals in each replicate $(n=15)$. Bars represent the mean $(n=4)$ for each treatment. Error bars represent SE $(n=4)$. Significant main effects and interactions appear in the upper left corner of each graph. Italics for the Temp $\times \mathrm{pH}$ interaction indicates an antagonistic interaction. Experimental conditions appear in Table S18, and statistics are presented in Tables S19-S22

compared to the warmer temperature treatment $\left(30^{\circ} \mathrm{C}\right)$ for juvenile $A$. irradians, where elevated temperature but normal $\mathrm{pH}$ and $\mathrm{DO}$ conditions yielded only $55 \%$ survival $\left(\mathrm{p}<0.0001\right.$; 3 -way ANOVA; $_{\text {; }}$ Table 1, Fig. $7 \mathrm{~A}_{\text {; }}$ Table S24). While low pH significantly reduced scallop survival $(p<0.0001)$, the lowest survival at either temperature was in the low 

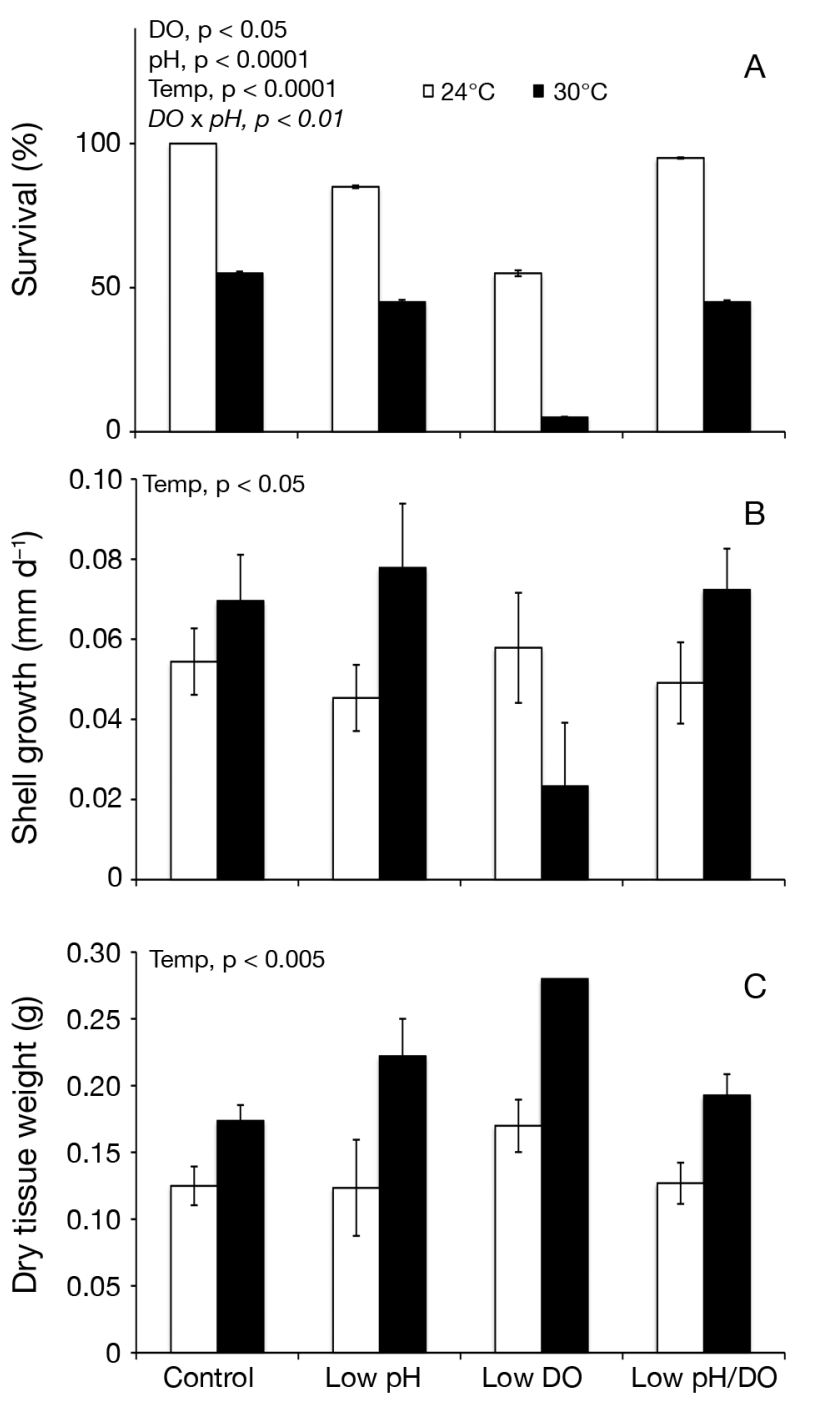

Fig. 7. As in Fig. 6, for larger Argopecten irradians (initial shell length $=13.71 \pm 0.78 \mathrm{~mm}, \mathrm{n}=5$ replicates). Experimental conditions appear in Table S23, and statistics are presented in Tables S24-S26

DO $\left(2.41 \pm 0.54 \mathrm{mg} \mathrm{l}^{-1}\right)$ treatment, where at $30^{\circ} \mathrm{C}$, only $5 \pm 0.5 \%$ of individuals survived $(\mathrm{p}<0.05 ; 3$-way ANOVA; Table 1, Fig. 7A; Table S24). There was again a significant $\mathrm{pH}-\mathrm{DO}$ interaction, as the low $\mathrm{pH} /$ low DO $\left(\mathrm{pH}_{\mathrm{T}}=7.24 \pm 0.01 ; \mathrm{DO}=3.22 \pm 0.16 \mathrm{mg}\right.$ $\mathrm{l}^{-1}$ ) treatments yielded survival rates higher than the low DO treatment alone ( $\mathrm{p}<0.05$; 3-way ANOVA; Table 1, Fig. 7A; Table S24). Length-based shell growth rates and tissue weights of individuals were significantly higher in the warmer temperature treatment $\left(30^{\circ} \mathrm{C}\right)$ compared to the colder temperature treatment $\left(24^{\circ} \mathrm{C}\right.$ ) for juvenile $A$. irradians $(\mathrm{p}<0.05$; 3-way ANOVA; Table 1, Fig. 7B,C; Tables S25 \& S26).

\section{Small juvenile Mercenaria mercenaria}

Both lower temperature and low pH significantly reduced the survival of small juvenile hard clams $(3.97 \pm 0.41 \mathrm{~mm} ; \mathrm{p}<0.0001$ for each $)$ while low DO did not (3-way ANOVA; Table 1, Fig. 8A; Tables S27 $\&$ S28). There were complex interactions between $\mathrm{pH}$ and temperature, and $\mathrm{pH}$ and $\mathrm{DO}$, as the combined

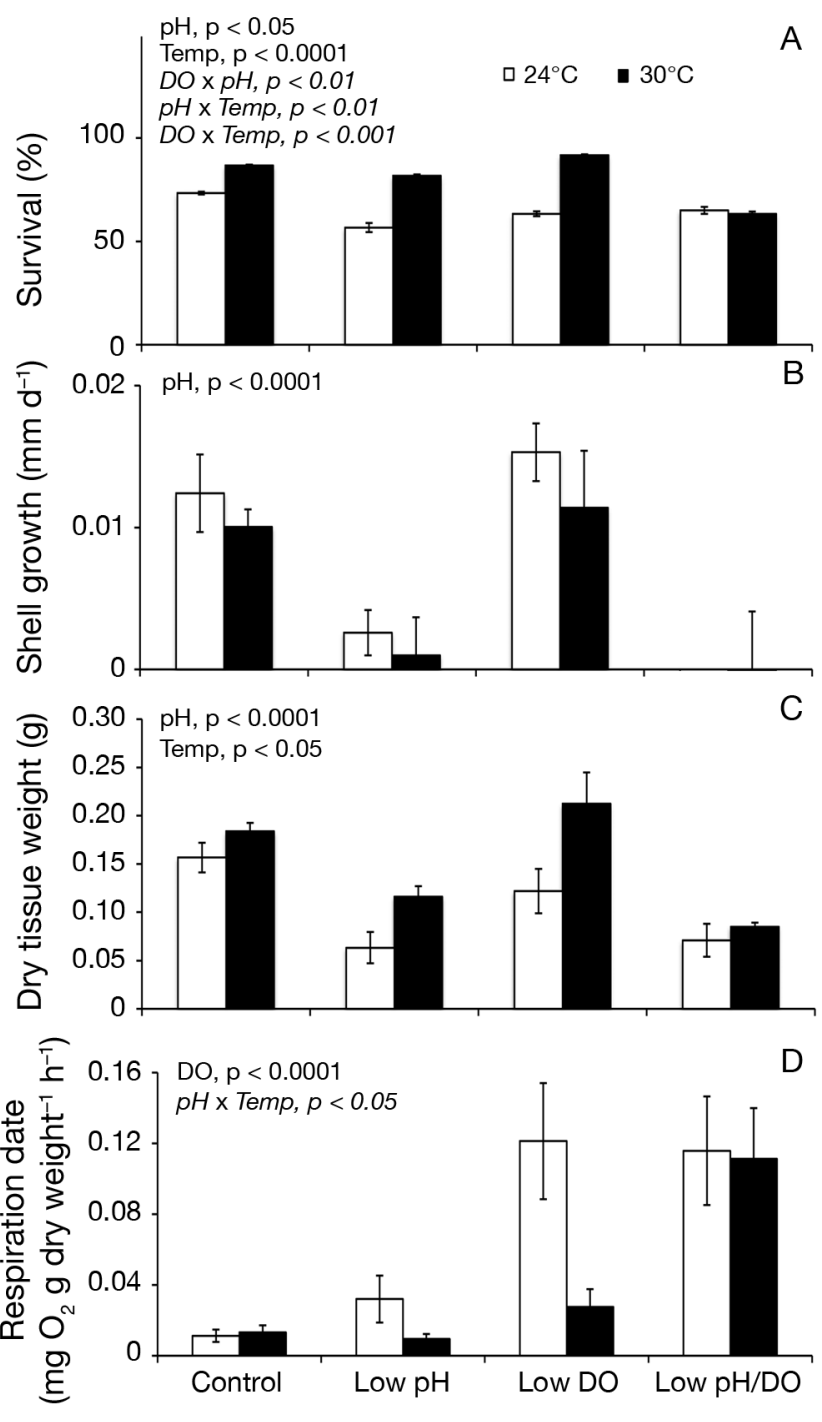

Fig. 8. (A) Survival, (B) shell growth, (C) dry tissue weight, and (D) respiration rates of smaller Mercenaria mercenaria exposed to thermal stress, acidification, and hypoxia experiment. Initial shell length was $3.97 \pm 0.41 \mathrm{~mm}$. Shell lengthbased growth rates and tissue weights were measured after a $21 \mathrm{~d}$ period. Dry tissue weights are pooled data for all individuals in each replicate $(n=15)$. Bars represent the mean $(n=$ $4)$ for each treatment. Error bars represent SE $(n=4)$. Significant main effects and interactions appear in the upper left corner of each graph. Italics for interactions indicate that they are antagonistic. Experimental conditions appear in Table S27, and statistics are presented in Tables S28-S31 
low $\mathrm{pH} /$ low DO treatments had a synergistic effect and the lowest survival $(63 \pm 2.1 \%)$ at $30^{\circ} \mathrm{C}\left(\mathrm{pH}_{\mathrm{T}}=\right.$ $7.24 \pm 0.07 ; \mathrm{DO}=2.92 \pm 0.28 \mathrm{mg} \mathrm{l}^{-1}$ ) but had an antagonistic effect on survival at $24^{\circ} \mathrm{C}(\mathrm{p}<0.01$; 3 -way ANOVA; Table 1, Fig. 8A; Table S28). At $24^{\circ} \mathrm{C}$, low $\mathrm{pH}\left(\mathrm{pH}_{\mathrm{T}}=7.232 \pm 0.05\right)$ yielded the lowest survival of the entire experiment $(57 \pm 4.4 \%)$, significantly lower than survival in normal $\mathrm{pH}$ and DO conditions at both temperatures $(73 \pm 1.4 \%$ and $87 \pm$ $0.8 \%$, respectively; Fig. 8A).

Low $\mathrm{pH}$ led to strong and significant reductions in the shell-based growth rates of small juvenile hard clams $(\mathrm{p}<0.0001)$ while temperature and DO did not (3-way ANOVA; Table 1, Fig. 8B; Table S29). Under high $\mathrm{pH}$, shell growth rates ranged from 0.010 to $0.015 \mathrm{~mm} \mathrm{~d}^{-1}$, whereas rates were 4 - to 10 -fold lower under low $\mathrm{pH}\left(0.0025-0.001 \mathrm{~mm} \mathrm{~d}^{-1}\right)$. There was a synergistic interaction between $\mathrm{pH}$ and $\mathrm{DO}$, as there was zero shell growth during the 4 wk experiments when clams experienced low $\mathrm{pH}$ and low DO concurrently $(\mathrm{p}<0.05$; 3 -way ANOVA; Table 1, Fig. 8B; Table S29).

Lower temperatures and low $\mathrm{pH}$ caused significant reductions in the tissue weights of small juvenile hard clams (3-way ANOVA; $\mathrm{p}<0.001$ for both; Table 1, Fig. 8C; Table S30), whereas low DO did not (3-way ANOVA; $p>0.05$ ). Low DO caused a significant $(p<0.0001)$ increase in the respiration rates of small juvenile hard clams, while low $\mathrm{pH}$ and temperature did not $(\mathrm{p}<0.05$; 3 -way ANOVA; Tables 1, Fig. $8 D_{;}$Table S31). Respiration rates under higher DO averaged $0.02 \mathrm{mg} \mathrm{O}_{2} \mathrm{~g}$ dry weight ${ }^{-1} \mathrm{~h}^{-1}$, whereas exposure to low DO raised these rates 3- to 7 -fold (Fig. 8D).

\section{Large juvenile Mercenaria mercenaria}

Both temperature and DO altered the survival of larger hard clams $(6.11 \pm 0.49 \mathrm{~mm})$ while $\mathrm{pH}$ did not ( $p<0.0001$ for each; 3 -way ANOVA; Table 1, Fig. 9A; Tables S32 \& S33). Survival was significantly greater in the warmer $\left(30^{\circ} \mathrm{C}\right)$ temperature $(93 \pm 0.8 \%$ control $)$ compared to the colder $\left(24^{\circ} \mathrm{C}\right)$ temperature treatment (63 $\pm 0.9 \%$ control) for juvenile M. mercenaria $(\mathrm{p}<$ 0.0001; 3-way ANOVA; Table 1, Fig. 9A; Table S33). At both temperatures, exposure to low DO significantly decreased survival, with the lowest survival $(25 \pm 2.4 \%)$ occurring in the low $\mathrm{pH} /$ low $\mathrm{DO}\left(\mathrm{pH}_{\mathrm{T}}=\right.$ $7.27 \pm 0.14 ; \mathrm{DO}=3.05 \pm 0.54 \mathrm{mg} \mathrm{l}^{-1}$ ) treatment at $24^{\circ} \mathrm{C}(\mathrm{p}<0.0001 ; 3$-way ANOVA; Table 1, Fig. 9A; Table S33). There was an interaction between $\mathrm{pH}$ and temperature that significantly altered survival,
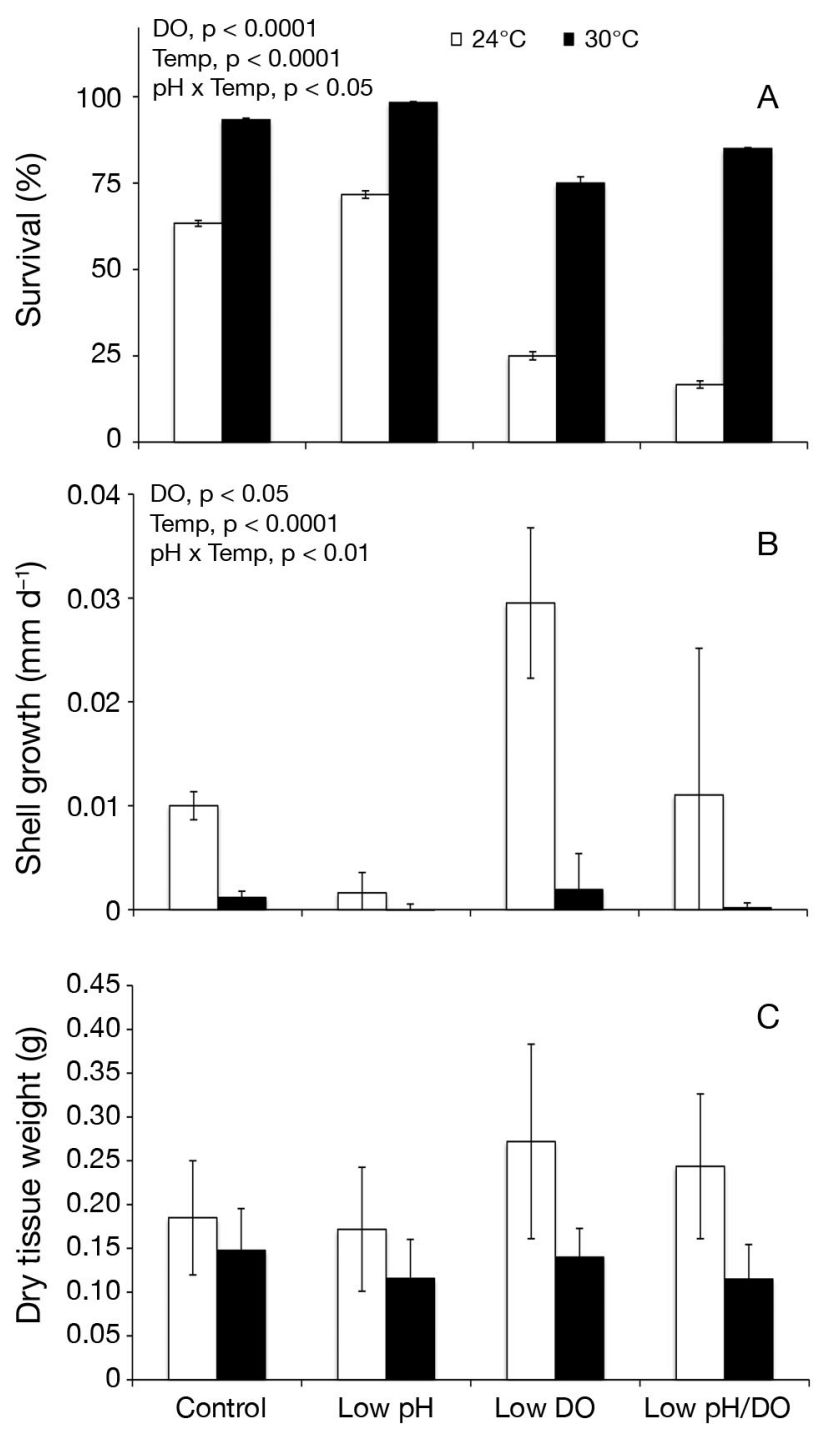

Fig. 9. (A) Survival, (B) shell growth, and (C) dry tissue weight of larger Mercenaria mercenaria juveniles in the thermal stress, acidification, and hypoxia experiment. Initial shell length was $6.11 \pm 0.80 \mathrm{~mm}$. Shell length-based growth rates and tissue weights were measured after a $30 \mathrm{~d}$ period. Dry tissue weights are pooled data for all individuals in each replicate $(n=15)$. Bars represent the mean $(n=4)$ for each treatment. Error bars represent SE $(n=4)$. Significant main effects and interactions appear in the upper left corner of each graph. Interactions were synergistic. Experimental conditions appear in Table S32, and statistics are presented in Tables S33-S35

whereby the combined low $\mathrm{pH}$ and low DO had the lowest survival at $24^{\circ} \mathrm{C}$ but yielded a survival higher than the low $\mathrm{DO}\left(\mathrm{DO}=2.82 \pm 0.2 \mathrm{mg} \mathrm{l}^{-1}\right)$ treatment at $30^{\circ} \mathrm{C}(\mathrm{p}<0.05 ; 3$-way ANOVA; Table 1, Fig. 9A; Table S33).

Length-based shell growth rates were significantly higher in the colder temperature treatment $\left(24^{\circ} \mathrm{C}\right)$ 
compared to the warmer temperature treatment $\left(30^{\circ} \mathrm{C}\right)(\mathrm{p}<0.0001)$ for juvenile $M$. mercenaria, whereas individuals exposed to low DO $\left(24^{\circ} \mathrm{C} ;\right.$ DO = $2.83 \pm 0.31 \mathrm{mg} \mathrm{l}^{-1}$ ) had significantly higher shell growth rates $(\mathrm{p}<0.05 ; 3$-way ANOVA; Table 1, Fig. 9B; Table S34). There was a significant synergistic interaction between $\mathrm{pH}$ and temperature, whereby there was no shell-based growth in low $\mathrm{pH}$ treatments at $30^{\circ} \mathrm{C}$ during the 4 wk experiment $(\mathrm{p}<$ 0.01; 3-way ANOVA; Table 1, Fig. 9B; Table S34). None of the experimental factors significantly altered the tissue weights of larger hard clams (Fig. 9C; Table S35).

\section{DISCUSSION}

Climate change is warming, deoxygenating, and acidifying coastal oceans (Doney et al. 2009, 2012, Hoegh-Guldberg \& Bruno 2010, Keeling et al. 2010). Individually, each of these processes can affect bivalves (Weiss et al. 2007, Levin et al. 2009, Talmage \& Gobler 2010), but the effects of these stressors may be species- and life stage-dependent (Pörtner 2008). While there has been extensive research on the effects of hypoxia or acidification on bivalves, studies examining both of these stressors concurrently at different temperatures have not been performed. During this study, hypoxia, acidification, and elevated temperatures all affected each species, with low $\mathrm{pH}$ and low DO conditions most consistently having a negative impact on survival, shell growth, tissue weights, and/or respiration rates. This study also revealed a consistent antagonistic effect between $\mathrm{pH}$ and DO on the performance of bivalves, while $\mathrm{pH}$ and temperature acted synergistically and antagonistically to alter outcomes for bivalves. The collective findings of this study, therefore, bring new insight and understanding with regard to the effects of climate change stressors on juvenile bivalves.

\section{Hypoxia}

Hypoxia has become an increasingly common occurrence in coastal zones (Diaz \& Rosenberg 2008, Doney et al. 2012) and is expected to expand as ocean temperatures continue to rise and DO levels subsequently decrease (Keeling et al. 2010, Rabalais et al. 2010). Hypoxic conditions can negatively affect the growth and survival of many marine organisms, including bivalves (Diaz \& Rosenberg 2008, Levin et al. 2009, Gobler et al. 2014). During this study, DO levels in low $\mathrm{O}_{2}$ treatments were typically between 2 and $3 \mathrm{mg} \mathrm{l}^{-1}$, levels that are within the upper range of hypoxic conditions (USEPA 2000) but were low enough to negatively impact the performance of juvenile bivalves in all but 1 of the 9 experiments, with Mytilus edulis being the exception. Collectively, low oxygen conditions led to significantly reduced survival in 5 of the 9 experiments and significantly lowered shell growth in 4 of 9 experiments. There was a range of sensitivities among species, as low DO caused significantly enhanced mortality in all 3 experiments involving Argopecten irradians, whereas Mercenaria mercenaria and Crassostrea virginica both experienced significantly lower survival in 1 of 2 experiments and $M$. edulis was relatively resistant to hypoxia, never experiencing heightened mortality and experiencing reduced shell growth in only 1 experiment. These differences may be related to the more rapid rates of shell growth and respiration in A. irradians compared to other bivalves (Kennedy et al. 1996, Kraeuter \& Castagna 2001, Shumway \& Parsons 2006, this study) and the more frequent exposure of mussels to an absence of oxygen when existing inter-tidally (Altieri 2006). We note that in 1 experiment, survival rates of our control treatment scallops were low $(25 \%)$, further evidencing the extreme sensitivity of these animals to DO levels.

Under hypoxic conditions, the tissue demand for oxygen of bivalves may not be met by ambient supply and thus a series of physiological adaptations are employed, including reducing oxygen demand via metabolic depression and switching from aerobic to anaerobic metabolism (Grieshaber et al. 1994, Guppy \& Withers 1999, Hochachka \& Lutz 2001). While anaerobic metabolic pathways enable an organism to survive hypoxia, these changes are energetically costly and considered to be short-term adaptive responses (DeFur \& Mangum 1979, Wu 2002). During this study, bivalves exposed to hypoxic conditions had significantly higher respiration rates than individuals persisting under normal oxygen conditions or exposed to other stressors. As noted in prior studies, bivalves regulate their rate of oxygen consumption with decreasing external oxygen concentrations by increasing the efficiency of oxygen removal from the water column (Hamwi \& Haskin 1969, Grizzle et al. 2001, Gurr et al. 2018), an observation evidencing the stress of low DO and potentially indicating the additional energy expended (ATP metabolized) during anaerobic metabolism. In some cases, such a metabolic adjustment allowed bivalves to persist normally. For example, for small hard clams, low oxygen led to enhanced respiration 
rates while shell growth and survival rates were unaltered, a finding consistent with other studies reporting that $M$. mercenaria can withstand deoxygenated environments (i.e. Narragansett Bay, Rhode Island, USA) and are somewhat hypoxia-tolerant (Altieri 2008, Levin et al. 2009). More commonly, however, low oxygen led to significantly reduced shell growth rates in bivalves ( $44 \%$ of experiments), an outcome associated with metabolic depression (Pörtner et al. 2005, Sokolova 2013, Gobler et al. 2014). In the extreme, the metabolic depression associated with hypoxia ultimately led to significantly increased mortality ( $55 \%$ of experiments), a common outcome under hypoxia in an ecosystem setting (Breitburg et al. 2009, Levin et al. 2009).

\section{Acidification}

Ocean acidification in coastal zones is a modernday occurrence. Beyond absorbing anthropogenic atmospheric $\mathrm{CO}_{2}$, eutrophication, river discharge, and upwelling can promote acidification and associated changes in carbonate chemistry in coastal waters (Doney et al. 2009, Wallace et al. 2014, Ekstrom et al. 2015). This combination of anthropogenic and natural factors contributing to lower saturation states of calcium carbonate can have short-term as well as long-term consequences for organisms that synthesize carbonate shell or skeleton including bivalves (Gobler \& Talmage 2013, Ekstrom et al. 2015, Gledhill et al. 2015). While the negative effects of acidification on bivalves have been well-documented, the multi-species, multi-age approach taken here both supports some prior hypotheses regarding the effects of acidification on juvenile bivalves and provides new insights. Firstly, of the 3 stressors investigated, low $\mathrm{pH}$ treatments significantly worsened the performance of juvenile bivalves less frequently ( $66 \%$ of experiments) than low DO (90\% of experiments) but more frequently than elevated temperature $(50 \%$ of experiments). Next, of the 4 bivalves examined here, A. irradians was the most vulnerable to low $\mathrm{pH}$, experiencing significantly higher mortality rates than control treatments in 2 of 3 experiments across multiple sized cohorts $(1.6-14 \mathrm{~mm})$. Both $M$. edulis and $M$. mercenaria experienced heightened mortality under low $\mathrm{pH}$ in 1 of 2 experiments, while $C$. virginica never experienced heightened mortality under low $\mathrm{pH}$. These observations collectively suggest that the order of sensitivity of the bivalves to acidification was $A$. irradians $>M$. edulis $=M$. mercenaria $>C$. virginica, which is generally consistent with prior stud- ies that have documented the high vulnerability of A. irradians to acidification and somewhat greater resistance for C. virginica (Talmage \& Gobler 2009, 2010, 2011, Gobler \& Talmage 2014). The greater sensitivity of $A$. irradians to acidification may be associated with its extremely rapid growth and respiration rates compared to other bivalves (Shumway \& Parsons 2006). Along with more rapid growth, the more rapid calcification of $A$. irradians also makes it more vulnerable to acidification, as Waldbusser et al. (2016) reported that early life stage bivalve species with rapid calcification rates are more vulnerable to acidification compared to slower-growing species.

Some experiments presented here also revealed a size-dependent sensitivity to acidification among the juvenile bivalves. For example, while the smaller cohort of $M$. mercenaria ( 4 $\mathrm{mm}$ ) experienced significantly reduced shell growth, tissue weight, and survival due to acidification, the $50 \%$ larger cohort $(\sim 6 \mathrm{~mm})$ did not. Similarly, while the smaller cohort of M. edulis $(5 \mathrm{~mm})$ experienced significantly heightened mortality due to acidification, the larger cohort $(12 \mathrm{~mm})$ did not. While cohort variance may have influenced results, these findings are consistent with prior studies that have similarly observed an age- or size-dependent sensitivity to acidification in bivalves (Green et al. 2009, Waldbusser et al. 2010, Gobler et al. 2014). Smaller juvenile bivalves are less capable of resisting dissolution pressure likely due to developmental shifts in shell mineralogy and rapid growth occurring in earlier life stage juveniles (Green et al. 2009, Waldbusser et al. 2010). The absence of a sizedependent effect for A. irradians and C. virginica was likely due to the points made above regarding their sensitivities to acidification, with the former being extremely sensitive at all size classes and the latter being robust against this stressor.

\section{Thermal stress}

As the oceans continue to warm, coastal organisms such as bivalves in shallower waters are increasingly likely to experience water temperatures beyond their physiological optimal condition (Rabalais et al. 2010, Doney et al. 2012). Warmer temperatures could accelerate metabolic rates of bivalves which may impact their growth rates (Hoegh-Guldberg \& Bruno 2010). Once an organism reaches its maximum thermal threshold, it is no longer able to adapt its physiological systems, increasing the risk of stress and mortality (Hoegh-Guldberg \& Bruno 2010). Physiologically, the demand for oxygen and the capacity of an organ- 
ism to maintain adequate oxygen supply to its tissues is the primary mechanism restricting tolerance to thermal extremes in invertebrates (Pörtner \& Knust 2007, Pörtner 2008). During this study, elevated temperature more consistently affected juvenile bivalve performance than low DO and low $\mathrm{pH}$, yielding altered, but not always lower, survival, shell growth, and/or tissue weight in every experiment.

Like acidification, the precise response of juvenile bivalves to elevated temperatures varied by species and size. Juvenile $C$. virginica and $M$. edulis were highly vulnerable to thermal stress, experiencing significant reductions in survival, shell growth, and/or tissue weight at elevated temperatures. A. irradians was moderately sensitive to elevated temperatures, with larger individuals $(14 \mathrm{~mm})$ displaying significantly reduced survival when exposed to elevated temperatures. In contrast, smaller juvenile A. irradians $(8 \mathrm{~mm})$ experienced increased survival under higher temperatures. Pörtner (2008) noted that larger individuals can be impacted by thermal stress more so than smaller individuals that may have a larger tolerable thermal range due to a lower total metabolic rate.

In contrast to the other 3 bivalve species that were negatively affected by elevated temperatures, 2 cohorts of $M$. mercenaria displayed significantly higher survival in warmer temperature $\left(30^{\circ} \mathrm{C}\right)$ compared to the control $\left(24^{\circ} \mathrm{C}\right)$ treatment, and the smaller juvenile hard clams also experienced higher final dry tissue weights in warmer water $\left(30^{\circ} \mathrm{C}\right)$. Similarly, the smaller cohort of bay scallops also experienced elevated survival at higher temperatures $\left(30^{\circ} \mathrm{C}\right)$ and even the larger cohort displayed more rapid shell growth and achieved higher tissue weights at higher temperatures. Given that the southern geographic range of both species extends into the Gulf of Mexico (Kennedy et al. 1996, Kraeuter \& Castagna 2001), their ability to benefit from elevated temperatures is perhaps not fully surprising. In addition, $M$. mercenaria in NY are prone to infections by Quahog Parasite Unknown (QPX) but generally go into disease remission at temperatures exceeding $27^{\circ} \mathrm{C}$ (Wang et al. 2016) and thus may have benefited from a reduced pathogen load under experimentally elevated temperatures used in the present study. Superimposed upon the general temperature tolerances of each species are likely localized adaptations to temperatures (Sunday et al. 2012). While the temperatures used here $\left(24-30^{\circ} \mathrm{C}\right)$ were only mildly stressful for individual collected from the mid-point (NY) of their latitudinal range (Canada to Gulf of Mexico), these levels may have had no effect on individuals within the southern range but could have been highly stressful to those from the northern extent of this range.

\section{Interactions}

During the past several decades, the consequences of warming, hypoxia, and acidification for marine life in general, and marine bivalves in particular, have been broadly investigated (Diaz \& Rosenberg 1995, Pörtner 2008, Levin et al. 2009, Gazeau et al. 2013). In contrast, the way combinations of these stressors may affect these organisms is not well understood. If these stressors were to additively affect organisms, their impacts could be estimated from prior research and single stressor studies. In the present study, however, stressors often interacted in a non-additive manner, altering the expected performance of bivalves in response to combinations of warming, hypoxia, and/or acidification.

Hypoxia and acidification are co-stressors in eutrophic coastal ecosystems and upwelling zones (Feely et al. 2010, Wallace et al. 2014, Gobler \& Baumann 2016, Cai et al. 2017, Baumann \& Smith 2018). The most common interaction among stressors observed during this study was between low $\mathrm{pH}$ and low DO, occurring in 7 of the 9 experiments performed. In many cases ( 6 of 7 experiments, including 2 with $A$. irradians, both with $C$. virginica, 1 with $M$. edulis, and 1 with $M$. mercenaria), this interaction was antagonistic whereby the shell growth and/or survival of the bivalves exposed to both low DO and low $\mathrm{pH}$ was higher than expected based on the outcome of exposure to the individual stressors. In extreme cases, the exposure to low $\mathrm{pH}$ completely mitigated the negative effects of low DO (e.g. large A. irradians survival, $C$. virginica survival of cohort exposed to 2 temperatures). While it is notable that the mean levels of DO in the combined low DO-low $\mathrm{pH}$ treatment were sometimes slightly higher than the low DO treatment, these differences were never statistically significant, while the interactions were. Such interactions have been observed previously for larval bivalves (Clark \& Gobler 2016) and indicates that physiological pathways that the stressors are acting upon are not independent. Other than calcification, low pH can have universal, cascading physiological effects on bivalves' performance by limiting feeding, lipid storage, and RNA synthesis, and increasing respiration rates (Gobler \& Talmage 2013, Waldbusser et al. 2015). Similarly, hypoxia has broad effects on multiple aspects of bivalve physiology 
(Diaz \& Rosenberg 1995, Vaquer-Sunyer \& Duarte 2008, Levin et al. 2009). Therefore, it is exceedingly likely that these 2 stressors can act upon some of the same physiological pathways that, once inhibited by one stressor, cannot be further depressed by the second stressor, accounting for the common antagonistic interaction among these stressors during this study.

The antagonistic effects of low $\mathrm{pH}$ and low DO on early life stage bivalve performance may also be related to the onset of anaerobic metabolism. In an ecosystem setting, hypoxia and acidification are often controlled by microbial respiration (Gobler \& Baumann 2016, Baumann \& Smith 2018), co-occur (Wallace et al. 2014, Baumann et al. 2015, Cai et al. 2017), and likely have done so for millions of years. As such, it seems likely that the biochemical pathways associated with anaerobic metabolism have adapted over evolutionary time to performing ideally under low oxygen and some level of hypercapnia. Indeed, some of the physiological pathways upregulated via anaerobic metabolism specifically induce acidosis (Grizzle et al. 2001, Pörtner et al. 2005). An absence of such a low $\mathrm{pH}$-low DO antagonism in larval bivalves (Gobler et al. 2014, Clark \& Gobler 2016) may indicate that enzymes active in anaerobic metabolism, which may function optimally under lower $\mathrm{pH}$, may not be fully active in larval stages. Juvenile Macoma balthica isolated from the Baltic Sea, which often experience hypoxia and acidification, display higher growth and survival when exposed to low $\mathrm{pH}$ and low DO compared to ambient conditions (Jansson et al. 2015), perhaps evidencing the adaptation of these populations and/or their biochemical pathways to these environmental conditions.

Prior to 2014, most studies examining the effects of hypoxia on marine life achieved low dissolved oxygen conditions by bubbling $\mathrm{N}_{2}$ gas, a process that removes both $\mathrm{O}_{2}$ and $\mathrm{CO}_{2}$ and thus creates hypoxia and hypercapnic conditions (Gobler et al. 2014). Such investigations could not have identified the antagonism created in bivalve physiology by coexposure to low $\mathrm{pH}$ and low DO that was identified here. The approach used in this study achieved by the use of combination of $\mathrm{N}_{2}$ and $\mathrm{CO}_{2}$ gas, however, revealed an important and novel insight regarding the antagonistic interaction between low $\mathrm{pH}$ and DO and their effects on bivalve physiology.

While the interactions between low $\mathrm{DO}$ and low $\mathrm{pH}$ were frequently antagonistic, in some cases they were synergistic. The mid-sized juvenile scallops experienced lower than expected survival in the combined low $\mathrm{pH} /$ low DO treatment. Larger juvenile M. edulis $(12 \mathrm{~mm})$ achieved tissue weights within the combined low $\mathrm{pH} /$ low DO treatment that were lower than expected based on the outcome of each individual treatment, evidencing synergy. Under hypoxia, tissue demand for oxygen is not met by ambient supply, and the ability of these organisms to tolerate secondary stressors such as acidification could be compromised (Pörtner et al. 2005, Sokolova 2013). Exposure to hypoxia could also reduce an organism's acid-base regulatory process making it more vulnerable to low $\mathrm{pH}$ (Pörtner 2008). With specific regard to low $\mathrm{DO}$ and low $\mathrm{pH}$, as these stressors inhibit metabolic rates, internal gas exchange may slow, intracellular oxygen levels may be reduced, and $\mathrm{CO}_{2}$ from respiration may accumulate, potentially exacerbating hypercapnia and thus further lowering metabolism. Further, another species of Mytilus (M. coruscus) experienced lowered hemocyte abundance under low DO and pH conditions (Sui et al. 2016), suggesting that acidification and hypoxia may increase disease risk. In the case of the larger $M$. edulis, individuals were not affected by acidification or hypoxia alone, but experienced reduced tissue weight when concurrently exposed to hypoxic and acidified conditions, a synergistic outcome previously observed in larger bivalves (Gobler et al. 2014).

A second common interaction during this study was between $\mathrm{pH}$ and temperature, with one-third of experiments yielding a non-additive outcome for at least 1 performance variable quantified. In 2 instances (larger $M$. mercenaria experiment and the midsize A. irradians experiment), the survival of the bivalves at the higher temperature and low $\mathrm{pH}$ was higher than would be predicted by the individual stressors, indicating that higher temperatures acted antagonistically with low $\mathrm{pH}$ to partly ameliorate the stress of acidification. The interaction for $M$. mercenaria was complex, however, as $\mathrm{pH}$ and temperature interacted synergistically to depress respiration rates in small $M$. mercenaria as well as causing a complete cessation of shell growth over a 4 wk period in the larger hard clam experiment. Hence, while elevated temperatures and low $\mathrm{pH}$ yielded minor improvements in survival for some bivalves, these underlying interactions reveal that physiological repression of shell growth and respiration under low $\mathrm{pH}$ would likely make sustained survival unlikely over extended periods of stress.

\section{CONCLUSION}

Bivalves are valuable economic and ecosystem resources. This study focused on the early life, juve- 
nile stages of bivalves present in temperate estuaries during summer when the stressors examined in the experiments (high temperature, low $\mathrm{pH}$, and low DO) are most intense (Wallace et al. 2014, Baumann et al. 2015, Cai et al. 2017, Baumann \& Smith 2018). These stressors are expected to interact with each other (Reynaud et al. 2003, Pörtner et al. 2005, HoeghGuldberg et al. 2007, Pörtner \& Farrell 2008, Pörtner 2008) and accelerate with climate change (Gruber 2011, Doney et al. 2012). The outcomes of experiments evidenced the strong negative effects that low $\mathrm{pH}$, low $\mathrm{DO}$, and elevated temperature can have on the growth and survival of 4 species of juvenile bivalves. It also revealed surprising interactions whereby combined stressors both worsened or, in some cases, partly mitigated the negative effects of these stressors. Collectively, these responses will need to be considered in planning and implementing management solutions for current and future bivalve fisheries and restoration projects.

Acknowledgements. This work was supported by New York Sea Grant Award R-FBM-38, the Laurie Landeau Foundation, the Simons Foundation, and the Chicago Community Trust. We have no significant competing financial, professional, or personal interests that might have influenced the materials presented in this manuscript. We gratefully acknowledge the assistance of Andrew Griffith, Robert McCabe, Brooke Morrell, Andrew Lundstrum, and Christopher Paparo, and we thank Drs. Bradley Peterson and Nils Volkenborn and 3 anonymous reviewers for helpful feedback on this manuscript.

\section{LITERATURE CITED}

Almada-Villela PC, Davenport J, Gruffydd LD (1982) The effects of temperature on the shell growth of young Mytilus edulis L. J Exp Mar Biol Ecol 59:275-288

Altieri AH (2006) Inducible variation in hypoxia tolerance across the intertidal-subtidal distribution of the blue mussel Mytilus edulis. Mar Ecol Prog Ser 325:295-300

Altieri AH (2008) Dead zones enhance key fisheries species by providing predation refuge. Ecology 89:2808-2818

*Baumann H, Doherty O (2013) Decadal changes in the world's coastal latitudinal temperature gradients. PLOS ONE 8:e67596

Baumann H, Smith EM (2018) Quantifying metabolically driven $\mathrm{pH}$ and oxygen fluctuations in US nearshore habitats at diel to interannual time scales. Estuaries Coasts 41:1102-1117

Baumann H, Wallace RB, Tagliaferri T, Gobler CJ (2015) Large natural $\mathrm{pH}, \mathrm{CO}_{2}$ and $\mathrm{O}_{2}$ fluctuations in a temperate tidal salt marsh on diel, seasonal, and interannual time scales. Estuaries Coasts 38:220-231

Beck MW, Brumbaugh RD, Airoldi L, Carranza A and others (2011) Oyster reefs at risk and recommendations for conservation, restoration, and management. Bioscience 61: $107-116$
Berge JA, Bjerkeng B, Pettersen O, Schaanning MT, Sigurd Øxnevad S (2006) Effects of increased sea water concentrations of $\mathrm{CO}_{2}$ on growth of the bivalve Mytilus edulis L. Chemosphere 62:681-687

Boyd PW, Lennartz ST, Glover DM, Doney SC (2015) Biological ramifications of climate-change-mediated oceanic multi-stressors. Nat Clim Chang 5:71-79

Breitburg D (2002) Effects of hypoxia, and the balance between hypoxia and enrichment, on coastal fishes and fisheries. Estuaries 25:767-781

Breitburg DL, Adamack A, Rose KA, Kolesar SE and others (2003) The pattern and influence of low dissolved oxygen in the Patuxent River, a seasonally hypoxic estuary. Estuaries 26:280-297

*Beitburg DL, Hondorp DW, Davias LA, Diaz RJ (2009) Hypoxia, nitrogen, and fisheries: integrating effects across local and global landscapes. Annu Rev Mar Sci 1: 329-349

Cai WJ, Hu X, Huang WJ, Murrell MC and others (2011) Acidification of subsurface coastal waters enhanced by eutrophication. Nat Geosci 4:766-770

* Cai WJ, Huang WJ, Luther GW III, Pierrot D and others (2017) Redox reactions and weak buffering capacity lead to acidification in the Chesapeake Bay. Nat Comm 8:369

* Carroll J, Gobler CJ, Peterson BJ (2008) Resource-restricted growth of eelgrass in New York estuaries: light limitation, and alleviation of nutrient stress by hard clams. Mar Ecol Prog Ser 369:51-62

Cerrato RM, Caron DA, Lonsdale DJ, Rose JM, Schaffner RA (2004) Effect of the northern quahog Mercenaria mercenaria on the development of blooms of the brown tide alga Aureococcus anophagefferens. Mar Ecol Prog Ser 281:93-108

Clark HR, Gobler CJ (2016) Diurnal fluctuations in $\mathrm{CO}_{2}$ and dissolved oxygen concentrations do not provide a refuge from hypoxia and acidification for early-life-stage bivalves. Mar Ecol Prog Ser 558:1-14

* Cooley SR, Doney SC (2009) Anticipating ocean acidification's economic consequences for commercial fisheries. Environ Res Lett 4:024007

* Crain CM, Kroeker K, Halpern BS (2008) Interactive and cumulative effects of multiple human stressors in marine systems. Ecol Lett 11:1304-1315

Dame RF (1996) Ecology of marine bivalves: an ecosystem approach. CRC Press, New York, NY

* DeFur PL, Mangum CP (1979) The effect of environmental variables on the heart rates of invertebrates. Comp Biochem Physiol A Physiol 62:283-294

Deutsch C, Ferrel A, Seibel B, Pörtner HO, Huey RB (2015) Climate change tightens a metabolic constraint on marine habitats. Science 348:1132-1135

Diaz RJ, Rosenberg R (1995) Marine benthic hypoxia: a review of its ecological effects and the behavioural responses of benthic macrofauna. Oceanogr Mar Biol Annu Rev 33:245-303

* Diaz RJ, Rosenberg R (2008) Spreading dead zones and consequences for marine ecosystems. Science 321:926-929

Dickson AG (1993) pH buffers for sea-water media based on the total hydrogen-ion concentration scale. Deep Sea Res I 40:107-118

* Doney SC, Fabry VJ, Feely RA, Kleypas JA (2009) Ocean acidification: the other $\mathrm{CO}_{2}$ problem. Annu Rev Mar Sci $1: 169-192$

*Doney SC, Ruckelshaus M, Duffy JE, Barry JP and others (2012) Climate change impacts on marine ecosystems. 
Annu Rev Mar Sci 4:11-37

Ekstrom JA, Suatoni L, Cooley SR, Pendleton LH and others (2015) Vulnerability and adaptation of US shellfisheries to ocean acidification. Nat Clim Chang 5:207-214

Feely RA, Alin SR, Newton J, Sabine CL and others (2010) The combined effects of ocean acidification, mixing, and respiration on $\mathrm{pH}$ and carbonate saturation in an urbanized estuary. Estuar Coast Shelf Sci 88:442-449

*Gazeau F, Parker LM, Comeau S, Gattuso JP and others (2013) Impacts of ocean acidification on marine shelled molluscs. Mar Biol 160:2207-2245

Gledhill DK, White MM, Salisbury J, Thomas H and others (2015) Ocean and coastal acidification off New England and Nova Scotia. Oceanography 28:182-197

Gobler CJ, Baumann H (2016) Hypoxia and acidification in ocean ecosystems: coupled dynamics and effects on marine life. Biol Lett 12:20150976

Gobler CJ, Talmage SC (2013) Short-and long-term consequences of larval stage exposure to constantly and ephemerally elevated carbon dioxide for marine bivalve populations. Biogeosciences 10:2241-2253

* Gobler CJ, Talmage SC (2014) Physiological response and resilience of early life-stage Eastern oysters (Crassostrea virginica) to past, present and future ocean acidification. Conserv Physiol 2:cou004

Gobler CJ, Lonsdale DJ, Boyer GL (2005) A review of the causes, effects, and potential management of harmful brown tide blooms caused by Aureococcus anophagefferens (Hargraves et Sieburth). Estuaries 28:726-749

Gobler CJ, DePasquale EL, Griffith AW, Baumann H (2014) Hypoxia and acidification have additive and synergistic negative effects on the growth, survival, and metamorphosis of early life stage bivalves. PLOS ONE 9:e83648

Green MA, Waldbusser GG, Reilly SL, Emerson K, O'Donnell S (2009) Death by dissolution: sediment saturation state as a mortality factor for juvenile bivalves. Limnol Oceanogr 54:1037-1047

Grieshaber MK, Hardewig I, Kreutzer U, Pörtner HO (1994) Physiological and metabolic responses to hypoxia in invertebrates. Rev Physiol Biochem Pharmacol 125:43-147

Grizzle RE, Bricelj VM, Shumway SE (2001) Physiological ecology of Mercenaria mercenaria. Dev Aquacult Fish Sci 31:305-382

Gruber N (2011) Warming up, turning sour, losing breath: ocean biogeochemistry under global change. Philos Trans R Soc A 369:1980-1996

Guppy M, Withers P (1999) Metabolic depression in animals: physiological perspectives and biochemical generalizations. Biol Rev Camb Philos Soc 74:1-40

* Gurr SJ, Goleski J, Lima FP, Seabra R, Gobler CJ, Volkenborn N (2018) Cardiac responses of the bay scallop Argopecten irradians to diel-cycling hypoxia. J Exp Mar Biol Ecol 500:18-29

Hamwi A, Haskin HH (1969) Oxygen consumption and pumping rates in the hard clam Mercenaria mercenaria: a direct method. Science 163:823-824

Helm MM, Bourne N, Lovatelli A (2004) Hatchery culture of bivalves: a practical manual. Food and Agriculture Organization of the United Nations (FAO), Rome

*Hochachka PW, Lutz PL (2001) Mechanism, origin, and evolution of anoxia tolerance in animals. Comp Biochem Physiol B Biochem Mol Biol 130:435-459

Hoegh-Guldberg O, Bruno JF (2010) The impact of climate change on the world's marine ecosystems. Science 328 : 1523-1528
Hoegh-Guldberg O, Mumby PJ, Hooten AJ, Steneck RS (2007) Coral reefs under rapid climate change and ocean acidification. Science 318:1737-1742

* Jansson A, Norkko J, Dupont S, Norkko A (2015) Growth and survival in a changing environment: combined effects of moderate hypoxia and low $\mathrm{pH}$ on juvenile bivalve Macoma balthica. J Sea Res 102:41-47

Keeling RF, Körtzinger A, Gruber N (2010) Ocean deoxygenation in a warming world. Annu Rev Mar Sci 2: 199-229

Kennedy VS, Newell RIE, Eble AF (1996) The eastern oyster: Crassostrea virginica. Maryland Sea Grant College, College Park, MD

Kraeuter JN, Castagna M (2001) Biology of the hard clam. Elsevier Science, New York, NY

Kevin LA, Ekau W, Gooday AJ, Jorissen F and others (2009) Effects of natural and human-induced hypoxia on coastal benthos. Biogeosciences 6:2063-2098

Lüthi D, Le Floch M, Bereiter B, Blunier T and others (2008) High-resolution carbon dioxide concentration record $650,000-800,000$ years before present. Nature 453: 379-382

Martínez ML, Intralawan A, Vázquez G, Pérez-Maqueo O, Sutton P, Landgrave R (2007) The coasts of our world: ecological, economic and social importance. Ecol Econ 63:254-272

* Melzner F, Thomsen J, Koeve W, Oschlies A and others (2013) Future ocean acidification will be amplified by hypoxia in coastal habitats. Mar Biol 160:1875-1888

* Millero FJ (2010) Carbonate constants for estuarine waters. Mar Freshw Res 61:139-142

Newell RI (2004) Ecosystem influences of natural and cultivated populations of suspension-feeding bivalve molluscs: a review. J Shellfish Res 23:51-62

*Nixon SW (1995) Coastal marine eutrophication: a definition, social causes, and future concerns. Ophelia 41: 199-219

*Nixon SW, Granger S, Buckley BA, Lamont M, Rowell B (2004) A one hundred and seventeen year coastal water temperature record from Woods Hole, Massachusetts. Estuaries 27:397-404

* Officer CB, Smayda TJ, Mann R (1982) Benthic filter feeding: a natural eutrophication control. Mar Ecol Prog Ser 9:203-210

* Pörtner HO (2008) Ecosystem effects of ocean acidification in times of ocean warming: a physiologist's view. Mar Ecol Prog Ser 373:203-217

* Pörtner HO (2010) Oxygen-and capacity-limitation of thermal tolerance: a matrix for integrating climate-related stressor effects in marine ecosystems. J Exp Biol 213: 881-893

* Pörtner HO, Farrell AP (2008) Physiology and climate change. Science 322:690-692

*Pörtner HO, Knust R (2007) Climate change affects marine fishes through the oxygen limitation of thermal tolerance. Science 315:95-97

* Pörtner HO, Langenbuch M, Michaelidis B (2005) Synergistic effects of temperature extremes, hypoxia, and increases in $\mathrm{CO}_{2}$ on marine animals: from Earth history to global change. J Geophys Res Oceans 110:C09S10

* Rabalais NN, Diaz RJ, Levin LA, Turner RE, Gilbert D, Zhang J (2010) Dynamics and distribution of natural and human-caused hypoxia. Biogeosciences 7:585-619

* Range P, Chícharo MA, Ben-Hamadou R, Piló D, FernandezReiriz MJ, Labarta U, Munari M (2014) Impacts of $\mathrm{CO}_{2}$ - 
induced seawater acidification on coastal Mediterranean bivalves and interactions with other climatic stressors. Reg Environ Change 14:19-30

Reynaud S, Leclercq N, Romaine Lioud S, Ferrier Pagés C, Jaubert J, Gattuso JP (2003) Interacting effects of $\mathrm{CO}_{2}$ partial pressure and temperature on photosynthesis and calcification in a scleractinian coral. Glob Change Biol 9: 1660-1668

Salisbury J, Green MA, Hunt C, Campbell J (2008) Coastal acidification by rivers: a threat to shellfish? EOS Trans Am Geophys Union 89:513-528

Shumway SE, Parsons GJ (2006) Scallops: biology, ecology, and aquaculture. Elsevier, Boston, MA

Sokolova IM (2013) Energy-limited tolerance to stress as a conceptual framework to integrate the effects of multiple stressors. Integr Comp Biol 53:597-608

Stickle WB, Kapper MA, Liu LL, Gnaiger E, Wang SY (1989) Metabolic adaptations of several species of crustaceans and molluscs to hypoxia: tolerance and microcalorimetric studies. Biol Bull (Woods Hole) 177:303-312

Sui Y, Kong H, Shang Y, Huang X, Wu F, Hu M, Wang Y (2016) Effects of short-term hypoxia and seawater acidification on hemocyte responses of the mussel Mytilus coruscus. Mar Pollut Bull 108:46-52

Sunday JM, Bates AE, Dulvy NK (2012) Thermal tolerance and the global redistribution of animals. Nat Clim Chang 2:686-690

Talmage SC, Gobler CJ (2009) The effects of elevated carbon dioxide concentrations on the metamorphosis, size, and survival of larval hard clams (Mercenaria mercenaria), bay scallops (Argopecten irradians), and Eastern oysters (Crassostrea virginica). Limnol Oceanogr 54: 2072-2080

Talmage SC, Gobler CJ (2010) Effects of past, present, and future ocean carbon dioxide concentrations on the growth and survival of larval shellfish. Proc Natl Acad Sci USA 107:17246-17251

Talmage SC, Gobler CJ (2011) Effects of elevated temperature and carbon dioxide on the growth and survival of larvae and juveniles of three species of Northwest Atlantic bivalves. PLOS ONE 6:e26941

Thomsen J, Melzner F (2010) Moderate seawater acidification does not elicit long-term metabolic depression in the

Editorial responsibility: Emily Carrington, Friday Harbor, Washington, USA blue mussel Mytilus edulis. Mar Biol 157:2667-2676

USEPA (United States Environmental Protection Agency) (2000) Ambient aquatic life water quality criteria for dissolved oxygen (saltwater): Cape Cod to Cape Hatteras. EPA-822-R-00-012. USEPA, Washington, DC

Vaquer-Sunyer R, Duarte CM (2008) Thresholds of hypoxia for marine biodiversity. Proc Natl Acad Sci USA 105: 15452-15457

Waldbusser GG, Bergschneider H, Green MA (2010) Sizedependent $\mathrm{pH}$ effect on calcification in post-larval hard clam Mercenaria spp. Mar Ecol Prog Ser 417:171-182

Waldbusser GG, Brunner EL, Haley BA, Hales B, Langdon CJ, Prahl FG (2013) A developmental and energetic basis linking larval oyster shell formation to acidification sensitivity. Geophys Res Lett 40:2171-2176

*Waldbusser GG, Hales B, Langdon CJ, Haley BA and others (2015) Ocean acidification has multiple modes of action on bivalve larvae. PLOS ONE 10:e0128376

Waldbusser GG, Gray MW, Hales B, Langdon CJ and others (2016) Slow shell building, a possible trait for resistance to the effects of acute ocean acidification. Limnol Oceanogr 61:1969-1983

*Wall CC, Peterson BJ, Gobler CJ (2008) Facilitation of seagrass Zostera marina productivity by suspension-feeding bivalves. Mar Ecol Prog Ser 357:165-174

*Wallace RB, Baumann H, Grear JS, Aller RC, Gobler CJ (2014) Coastal ocean acidification: the other eutrophication problem. Estuar Coast Shelf Sci 148:1-13

Wang K, Espinosa EP, Allam B (2016) Effect of 'heat shock' treatments on QPX disease and stress response in the hard clam, Mercenaria mercenaria. J Invertebr Pathol 138:39-49

Weiss MB, Curran PB, Peterson BJ, Gobler CJ (2007) The influence of plankton composition and water quality on hard clam (Mercenaria mercenaria L.) populations across Long Island's south shore lagoon estuaries (New York, USA). J Exp Mar Biol Ecol 345:12-25

WWu RSS (2002) Hypoxia: from molecular responses to ecosystem responses. Mar Pollut Bull 45:35-45

* Zhang J, Gilbert D, Gooday AJ, Levin L and others (2010) Natural and human-induced hypoxia and consequences for coastal areas: synthesis and future development. Biogeosciences 7:1443-1467

Submitted: October 29, 2017; Accepted: August 15, 2018 Proofs received from author(s): September 21, 2018 